\title{
KONDISI KUALITAS AIR BAKU INSTALASI NGAGEL PERUSAHAN DAERAH AIR MINUM (PDAM) KOTA SURABAYA
}

\author{
Nusa Idaman Said dan Dinda Rita Krishumartani Hartaja \\ Pusat Teknologi Lingkungan, BPPT, Kawasan Puspiptek, Tangerang Selatan, 15314, Indonesia \\ Email : nusaidamansaid@gmail.com ; dindahartaja@gmail.com
}

\begin{abstract}
ABSTRAK
Saat ini PDAM Kota Surabaya mempunyai kapasitas pengolahan total sekitar 10.500 liter per detik yang terdiri dari beberapa instalasi yaitu IPA Karang Pilang I, IPA Karang Pilang II, IPA Karang Pilang III, IPA Ngagel I, IPA Ngagel II dan IPA Ngagel III. Kapasitas total instalasi pengolahan air Ngagel I sebesar 1800 liter per detik, dan Ngagel II sebesar 1000 liter per detik, sedangkan kapasitas instalsi pengolahan air Ngagel III sebesar 1.750 liter per detik. Air baku yang digunakan adalah air sungai yang diambil dari sungai Surabaya. Seiring pesatnya pertumbuhan pemukiman dan perkembangan sektor industri, mengakibatkan semakin tingginya tingkat pencemaran Sungai Surabaya. Hal tersebut berpengaruh pada menurunnya kualitas air oleh polutan khususnya polutan organik dari limbah domestik maupun limbah industri. Akibatnya Sungai Surabaya memiliki kualitas air baku yang kurang memenuhi ketentuan baku mutu yang dipersyaratkan sebagai air baku air minum. Untuk mengetahui kondisi tingkat pencemaran di dalam air sungai salah satu metoda yang banyak digunakan adalah dengan menentukan indeks pencemaran (IP). Penelitian ini bertujuan untuk mengetahui kondisi kualitas air baku di intake Ngagel serta menentukan tingkat pencemaran dengan menggunakan metoda indeks pencemaran. Penelitian ini dilakukan dengan menggunakan data sampling kualitas air di intake Ngagel yang dilakukan oleh PDAM dari tahun 2015 sampai dengan tahun 2017. Dengan menggunakan perhitungan Indeks Pencemaran (IP), dapat diketahui bahwa tingkat pencemaran air di Intake Ngagel tahun 2015 - 2017 tergolong dalam pencemaran sedang hingga pencemaran berat. Parameter yang paling potensial menyebabkan tingkat pencemaran tersebut adalah COD, BOD, Zat Organik serta konsentrasi oksigen terlarut (DO). Konsentrasi polutan organik dalam sungai tersebut telah melebihi baku mutu air kelas I berdasarkan PP No 82 tahun 2001, yakni untuk peruntukan air baku air minum. Dari tahun 2015 hingga 2016, terjadi peningkatan tingkat pencemaran, tetapi pada tahun 2017 tingkat cemaran cenderung sedikit mengalami penurunan dibandingkan dengan 2 (dua) tahun sebelumnya. Salah satu alternatif untuk meningkatkan kualitas air baku di Intake Ngagel yang yang diambil dari Sungai Surabaya adalah dengan menggunakan sistem biofilter.

Dengan proses biofiltrasi konsentrasi polutan organik, amoniak, detergen, padatan tersuspensi, zat besi, mangan akan dapat diturunkan sehingga konsumsi bahan kimia khususnya koagulan dan khlor untuk pengolahan air minum menjadi berkurang. Dengan demikian biaya produksi pengolahan air juga akan menjadi berkurang. Dengan semakin rendahnya konsentrasi amoniak di dalam air baku, maka penggunaan khor juga akan semakin sedikit, sehingga kemungkinan terjadinya senyawa hasil samping khlorinasi misalnya trihalometan juga semakin kecil.
\end{abstract}

Kata Kunci : Biofilter, IPA, Kualitas Air

\section{THE CONDITION OF THE RAW WATER QUALITY OF THE NGAGEL INSTALATION OF SURBAYA CITY WATER PURIFICATION PLANT}

\author{
Nusa Idaman Said \& Dinda Rita Krishumartani Hartaja \\ Center for Environmental Technology, BPPT, Puspiptek Area, South Tangerang, 15314, Indonesia \\ Email: nusaidamansaid@gmail.com ; dindahartaja@gmail.com
}

\begin{abstract}
ABSTRCT
Currently Surabaya City Drinking Water Company has a total processing capacity of around 10,500 liters per second consisting of several installations namely Karang Pilang I, Karang Pilang II, Karang Pilang III, Ngagel I, Ngagel II and Ngagel III Plant. The total capacity of the Ngagel I Plant is 1800 liters per second, and Ngagel II Plant is 1000 liters per second, while the installation capacity of the Ngagel III Plant is 1,750 liters per second. The raw water used is river water taken from the Surabaya river. Along with the rapid growth of settlements and the development of the industrial sector, resulting in higher levels of pollution in the Surabaya River. This affects the decreasing quality of water by pollutants, especially organic
\end{abstract}


pollutants from domestic and industrial waste. As a result, Surabaya River has raw water quality that does not meet the quality standard requirements required as raw water for drinking water. To determine the condition of the level of pollution in river water, one method that is widely used is to determine the pollution index (IP). This study aims to determine the condition of the quality of raw water in the Ngagel intake and determine the level of pollution using the pollution index method. This research was conducted using water quality sampling data at the Ngagel intake carried out by PDAMs from 2015 to 2017. By calculating the Pollution Index (IP), it can be seen that the level of water pollution in the Ngagel Intake in 2015 - 2017 is classified as moderate to heavy pollution. The most potential parameter causes the level of pollution is COD, BOD, Organic Substance and dissolved oxygen concentration (DO). The concentration of organic pollutants in the river has exceeded class I water quality standards based on PP No. 82 of 2001, namely for allotment of raw water for drinking water. From 2015 to 2016, there was an increase in pollution levels, but in 2017 the level of contamination tended to decrease slightly compared to the previous 2 (two) years. One alternative to improve the quality of raw water in the Ngagel intake that is taken from the Surabaya River is by using a biofilter system.

With the biofiltration process of concentrations of organic pollutants, ammonia, detergents, suspended solids, iron, manganese will be reduced so that the consumption of chemicals, especially coagulants and chlorine for processing drinking water is reduced. Thus the cost of producing water treatment will also be reduced. With the lower concentration of ammonia in raw water, the use of chlorine will also be less, so the possibility of the occurrence of chlorination by-products such as trihalomethane is also getting smaller.

Keywords: Biofilter, WTP, Water Quality

\section{PENDAHULUAN}

Saat ini PDAM Kota Surabaya mempunyai kapasitas pengolahan total sekitar 10.500 liter per detik yang terdiri dari beberapa instalasi yaitu IPA Karang Pilang I, IPA Karang Pilang II, IPA Karang Pilang III, IPA Ngagel I, IPA Ngagel II dan IPA Ngagel III (Yunianto dan Ciptomulyono). Kapasitas total instalasi pengolahan air Ngagel I sebesar 1800 liter per detik, dan Ngagel II sebesar 1000 liter per detik, sedangkan kapasitas instalsi pengolahan air Ngagel III sebesar 1.750 liter per detik (Annonim ; 2018).

Air baku yang digunakan adalah air sungai yang berasal dari Sungai Surabaya. Sungai Surabaya mengalir dari Mojokerto ke Surabaya sepanjang $39,5 \mathrm{~km}$ terletak pada bujur $112^{\circ} 30^{\prime}$ sampai $112^{\circ} 45^{\prime}$ BT dan lintang $7^{\circ} 15^{\prime}$ LS sampai $7^{\circ} 25^{\prime} \mathrm{LS}$. Sungai tersebut merupakan anak muara Brantas dimulai dari Mlirip, Mojokerto melewati daerah Wringin Anom, Driyorejo dan Sepanjang sebelum sampai ke Surabaya. Di Wonokromo, Kali Surabaya terpecah menjadi dua anak Kali yaitu Kali Mas dan Kali Wonokromo atau sering disebut Kali Jagir (Priyono, T.S.C. et. Al ; 2013). Sungai Surabaya merupakan sumber air baku untuk kebutuhan pemanfaat di wilayah Surabaya dan sekitarnya, termasuk bagi industri dan PDAM kota Surabaya (Annonim ; 2012).

Proses pengolahan air minum di PDAM Surabaya masih menggunakan proses konvesonal yaitu proses pengolahan air minun dengan pengendapan kimia. Air baku dialirkan ke bangunan intake yang dilengkapi dengan Saringan kasar untuk menyaring sampah agar tidak masuk ke instalasi pengolahan. Sealnjutnya air dilairkan ke bak Pra sedimentasi melalui kanal atau saluran terbuka. Selanjutnya, air di alirkan ke bak distributor, kemudian masuk ke accelator atau Clarifier sambil dibubuhkan larutan bahan koagulan (Aluminum sulfat) untuk menggumpalkan dan mengendapkan kotoran yang ada di dalam air. Di dalam tangki Accelator tersebut kotran akan digumpalkan dan diendapkan, selanjutnya kotoran yang sudah mengendap dibuang, dan air limpasan dari tangki accelator yang sudah jernih masuk ke unit saringan pasir cepat (rapid sand filter) yang bekerja secara gravitasi. Saringan pasir cepat tersebut berfungsi untuk menyaring gumpalan kotoran (flok) halus yang belum terendapkan di tangki clarifier. Air yang sudah melalui saringan pasir adalah air olahan yang sudah bersih, dan selanjutnya dialirkan ke bak penampung (reservoir) sambil diinjeksi dengan khlorin untuk membunuh kuman (Annonim ; 2017).

Seiring pesatnya pertumbuhan pemukiman dan perkembangan sektor industri, mengakibatkan semakin tingginya tingkat pencemaran Sungai Surabaya. Hal tersebut berpengaruh pada menurunnya kualitas air oleh polutan khususnya polutan organik dari limbah domestik maupun limbah industri. Akibatnya Sungai Surabaya memiliki kualitas air baku yang kurang memenuhi ketentuan baku mutu yang dipersyaratkan sebagai air baku air minum (Annonim ; 2001).

Selama sepuluh tahun terakhir pencemaran di Sungai Surabaya semakin memburuk. Pencemaran tidak hanya berasal dari limbah domestik tetapi juga berasal dari industri yang ada di sekitar Sungai Surabaya. 
Berdasarkan data dari stasiun monitoring Cangkir Tambangan, Bambe Tambangan dan Karangpilang tahun 2007-2011, status mutu air di Sungai Surabaya menurut metode STORET $49,44 \%$ adalah tercemar berat untuk peruntukkan kelas dua. Sedangkan status mutu air di Sungai Surabaya menurut metode Indeks pencemaran $100 \%$ adalah tercemar sedang untuk peruntukkan kelas dua. (Priyono, T.S.C. et. Al ; 2013)

Dengan semakin buruknya kualitas air baku, maka biaya produksi pengolahan air minum menjadi semakin besar pula. Untuk menghilangkan kotoran dalam air baku misalnya zat organik, padatan tersuspensi, bau dan juga bakteri patogen, banyak menggunakan bahan koagulan, dan senyawa khlorin untuk membunuh bakteri patogen misalnya senyawa khlorin untuk proses disinfeksi, dan semuanya itu meninggalkan zat sisa (residu) atau produk hasil samping di dalam air olahannya (finished water) (Sheftiana, Sarach, el all ; 2017). Selain itu dengan semakin buruknya kualtas air sungai surabaya khususnya di intake instalasi Ngagel, mengakibatkan biaya produksi menjadi meningkat, serta berpengaruh terhadap kualitas air olahan. Untuk mengetahui kondisi tingkat pencemaran di dalam air sungai salah satu metoda yang banyak digunakan adalah dengan menentukan indeks pencemaran (IP) (Kepmen LH No 115 Tahun 2003).

Penelitian ini bertujuan untuk mengetahui kondisi kualitas air baku di intake Ngagel serta menentukan tingkat pencemaran dengan menggu-nakan metoda indeks pencemaran.

\section{METODOLOGI}

Metode analisa data untuk menentukan status mutu air, baik air sungai, air danau waduk, dan air tanah adalah dengan menggunakan Metode Indeks Pencemaran, sesuai dengan Keputusan Menteri Negara Lingkungan Hidup Nomor 115 Tahun 2003 tentang pedoman penetuan status mutu air.

\subsection{Metode Indeks Pencemaran}

Sumitomo dan Nemerow (1970), Universitas Texas, A.S., mengusulkan suatu indeks yang berkaitan dengan senyawa pencemar yang bermakna untuk suatu peruntukan. Indeks ini dinyatakan sebagai Indeks Pencemaran (Pollution Index) yang digunakan untuk menentukan tingkat pencemaran relatif terhadap parameter kualitas air yang diizinkan(10) (Nemerow, 1974). Indeks ini memiliki konsep yang berlainan dengan Indeks Kualitas Air (Water Quality Index). Indeks Pencemaran (IP) ditentukan untuk suatu peruntukan, kemudian dapat dikembangkan untuk beberapa peruntukan bagi seluruh bagian badan air atau sebagian dari suatu sungai.

Pengelolaan kualitas air atas dasar Indeks Pencemaran (IP) ini dapat memberi masukan pada pengambil keputusan agar dapat menilai kualitas badan air untuk suatu peruntukan serta melakukan tindakan untuk memperbaiki kualitas jika terjadi penurunan kualitas akibat kehadiran senyawa pencemar. IP mencakup berbagai kelompok parameter kualitas yang independent dan bermakna.

\subsubsection{Prosedur Penggunaan}

Jika $L_{i j}$ menyatakan konsentrasi parameter kualitas air yang dicantumkan dalam Baku Mutu suatu Peruntukan Air, (j), dan $C_{i}$ menyatakan konsentrasi parameter kualitas air (i) yang diperoleh dari hasil analisis cuplikan air pada suatu lokasi pengambilan cuplikan dari suatu alur sungai, maka $\mathrm{Pl}_{\mathrm{j}}$ adalah Indeks Pencemaran bagi peruntukan (j) yang merupakan fungsi dari $C_{i} / L_{i j}$. Harga $\mathrm{Pl}_{\mathrm{j}}$ ini dapat ditentukan dengan cara :

a. Pilih parameter-parameter yang jika harga parameter rendah maka kualitas air akan membaik.

b. Pilih konsentrasi parameter baku mutu yang tidak memiliki rentang.

c. Hitung harga $C_{i} / L_{i j}$ untuk tiap parameter pada setiap lokasi pengambilan cuplikan.

d. Jika nilai konsentrasi parameter yang menurun menyatakan tingkat pencemaran meningkat, misal DO. Tentukan nilai teoritik atau nilai maksimum $\mathrm{C}_{\mathrm{im}}$ (misal untuk $\mathrm{DO}$, maka $C_{i m}$ merupakan nilai $D O$ jenuh). Dalam kasus ini nilai $C_{i} / L$ ij hasil pengukuran digantikan oleh nilai $C_{i} / L_{i j}$ hasil perhitungan, yaitu :

$$
\left(C_{i} / L_{i j}\right)_{\text {baru }}=\frac{C_{i m}-C_{i \text { (hasil pengukuran) }}}{C_{i m}-L_{i j}}
$$

e. Jika nilai baku $L_{i j}$ memiliki rentang :

- Untuk $\mathrm{C}_{\mathrm{i}} \leq \mathrm{L}_{\mathrm{ij}}$ rata - rata

$$
\left(C_{i} / L_{i j}\right)_{b a r u}=\frac{\left[C_{i}-\left(L_{i j}\right)_{\text {rata-rata }}\right]}{\left\{\left(L_{i j}\right)_{\text {minimum }}-\left(L_{i j}\right)_{\text {rata-rata }}\right\}}
$$

- Untuk $\mathrm{C}_{\mathrm{i}}>\mathrm{L}_{\mathrm{ij}}$ rata - rata

$\left(C_{i} / L_{i j}\right)_{\text {baru }}=\frac{\left[C_{i}-\left(L_{i j}\right)_{\text {rata-rata }}\right]}{\left\{\left(L_{i j}\right)_{\text {maksimum }}-\left(L_{i j}\right)_{\text {rata-rata }}\right\}}$

f. Keraguan timbul jika dua nilai $\left(\mathrm{C}_{\mathrm{i}} / \mathrm{L}_{\mathrm{ij}}\right)$ berdekatan dengan nilai acuan 1,0 , misal $C_{1}$ $/ L_{1 j}=0,9$ dan $C_{2} / L_{2 j}=1,1$ atau perbedaan yang sangat besar, misal $C_{3} / L_{3 j}=5,0$ dan $C_{4}$ 
$L_{4 j}=10,0$. Dalam contoh ini tingkat kerusakan badan air sulit ditentukan. Cara untuk mengatasi kesulitan ini adalah :

- Penggunaan nilai $\left(\mathrm{C}_{\mathrm{i}} / \mathrm{L}_{\mathrm{ij}}\right)$ hasil pengukuran kalau nilai ini lebih kecil dari 1,0.

- Penggunaan nilai $\left(C_{i} / L_{i j}\right)$ baru jika nilai $\left(C_{i} / L_{i j}\right)$ hasil pengukuran lebih besar dari 1,0. Persamaan $\left(C_{i} / L_{i j}\right)_{\text {baru }}$ adalah sebagai berikut:

$$
\left(C_{i} / L_{i j}\right)_{\text {baru }}=1,0+P \cdot \log \left(C_{i} / L_{i j}\right)_{\text {hasil pengukuran }}
$$

$\mathrm{P}$ adalah konstanta dan nilainya ditentukan dengan bebas dan disesuaikan dengan hasil pengamatan lingkungan dan atau persyaratan yang dikehendaki untuk suatu peruntukan (biasanya digunakan nilai 5).

g. Tentukan nilai rata-rata dan nilai maksimum dari keseluruhan $C_{i} / L_{i j}\left(\left(C_{i} / L_{i j}\right)_{R}\right.$ dan $\left.\left(C_{i} / L_{i j}\right)_{M}\right)$.

h. Tentukan harga $\mathrm{Pl} j$, dengan persamaan dibawah ini

$$
P I_{j}=\sqrt{\frac{\left(C_{i} / L_{i j}\right)_{M}^{2}+\left(C_{i} / L_{i j}\right)_{R}^{2}}{2}}
$$

\begin{tabular}{|c|c|}
\hline $\begin{array}{l}0 \leq \mathrm{PI}_{\mathrm{j}} \leq 1,0 \\
1,0<\mathrm{PI}_{\mathrm{j}} \leq 5,0 \\
5,0<\mathrm{PI}_{\mathrm{j}} \leq 10,0 \\
\mathrm{PI}_{\mathrm{j}}>10,0\end{array}$ & $\begin{array}{l}\rightarrow \text { memenuhi baku mutu } \\
\rightarrow \text { cemar ringan } \\
\rightarrow \text { cemar sedang } \\
\rightarrow \text { cemar berat }\end{array}$ \\
\hline
\end{tabular}

Evaluasi terhadap nilai PI adalah :

\subsection{Data dan Analisa}

Pada penelitian ini dilakukan dengan menggunakan data sampling kualitas air di intake Ngagel yang dilakukan oleh PDAM dari tahun 2015 sampai dengan tahun 2017.

\section{HASIL DAN PEMBAHASAN}

\subsection{Kondisi Kualitas Air}

\subsubsection{Konsentrasi COD}

Konsentrasi COD rata-rata bulanan pada tahun 2015 berkisar antara $10 \mathrm{mg} / \mathrm{l}$ - 15,42 mg/l. konsentrasi rata-rata bulanan tertinggi terjadi pada bulan November dan konsentarsi rata-rata bulanan terendah terjadi pada bulan September.

Konsentrasi COD rata-rata bulanan pada tahun 2016 berkisar antara 13,35 mg/l - 18,82 $\mathrm{mg} / \mathrm{l}$. konsentrasi rata-rata bulanan tertinggi terjadi pada bulan Oktober dan konsentarsi ratarata bulanan terendah terjadi pada bulan Maret.

Konsentrasi COD rata-rata bulanan pada tahun 2017 berkisar antara 12,94 mg/l - 19,26 $\mathrm{mg} / \mathrm{l}$. konsentrasi rata-rata bulanan tertinggi terjadi pada bulan Mei dan konsentarsi rata-rata bulanan terendah terjadi pada bulan Oktober.
COD rata-rata tahun 2015, 2016 dan 2017 masing-masing sebesar 13,7 mg/l, 14,93 mg/l dan 16,56 mg/l. Konsentrasi COD Air Baku di Instalasi Ngagel PDAM Surya Sembada Surabaya Dari Tahun 2018 - Tahun 2017 dapat dilihat pada Gambar 1.

Jika dibandingkan dengan baku peruntukan air sesuai dengan PP No.82 Tahun 2001 tentang Pengelolaan Kualitas Air dan Pengendalian Pencemaran Air, maka air intake Ngagel masuk dalam kriteria peruntukan air Kelas 2, yakni air yang peruntukannya dapat digunakan untuk prasarana/sarana rekreasi air, pembudidayaan ikan air tawar, peternakan, air untuk mengairi pertanaman, dan atau peruntukkan lain yang mempersyaratkan mutu air yang sama dengan kegunaan tersebut dengan konsentrasi COD maksimum 25 mg/l.

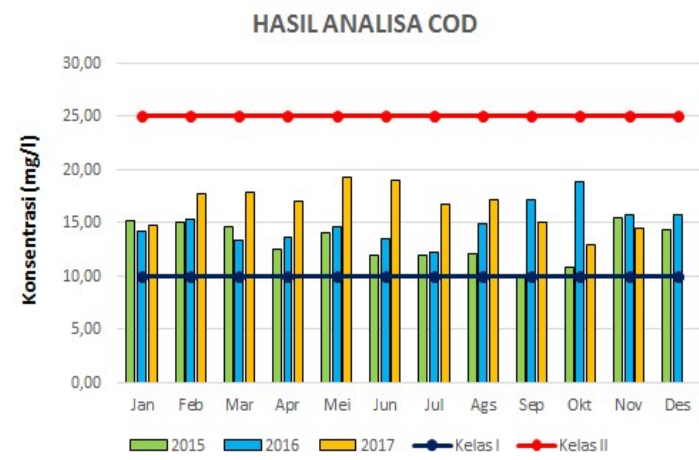

Gambar 1 : Konsentrasi COD Air Baku di Instalasi Ngagel PDAM Surya Sembada Surabaya Dari Tahun 2018 - Tahun 2017.

Untuk peruntukan air Kelas 1, yakni air yang peruntukannya dapat digunakan untuk air baku air minum, dan atau peruntukan lain yang mempersyaratkan mutu air yang sama dengan kegunaan tersebut, konsentrasi COD maksimum adalah $10 \mathrm{mg} / \mathrm{l}$. Jika dibandingkan dengan mutu air kelas 1, maka konsentrasi COD di intake Ngagel hampir sepanjang tahun sudah melampaui baku mutu air kelas 1 .

\subsubsection{Konsentrasi Zat Organik $\left(\mathrm{KMnO}_{4}\right)$}

Untuk konsentrasi Zat Organik $\left(\mathrm{KMnO}_{4}\right)$, dari tahun 2015 sampai dengan tahun 2017 berkisar antara 8,05 mg/l - 24,07 mg/l. Grafik konsentrasi Zat Organik $\left(\mathrm{KMnO}_{4}\right)$ rata-rata bulanan Intake IPA Ngagel PDAM Surya Sembada Surabaya Tahun 2015-2017 dapat dilihat pada Gambar 2. Jika dibandingkan dengan baku peruntukan air sesuai dengan PP No.82 Tahun 2001 tentang Pengelolaan Kualitas Air dan Pengendalian Pencemaran Air, maka konsentrasi zat organik air intake Ngagel masuk dalam kriteria peruntukan air Kelas 2. 


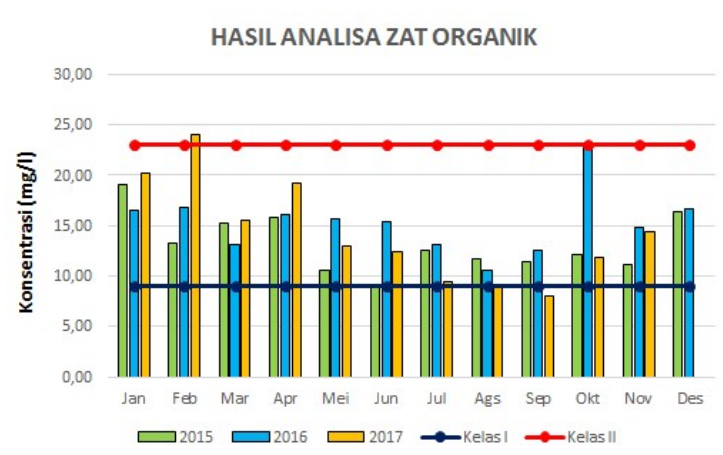

Gambar : Konsentrasi Zat Organik $\left(\mathrm{KMnO}_{4}\right)$ Air Baku di Instalasi Ngagel PDAM Surya Sembada Surabaya Dari Tahun 2018 - Tahun 2017

\subsubsection{Konsentrasi BOD}

Konsentrasi $B O D$ rata-rata bulanan Intake IPA Ngagel PDAM Surya Sembada Surabaya Tahun 2015-2017 berkisar antara 6,25 mg/l $12,50 \mathrm{mg} / \mathrm{l}$, seperti terlihat pada Gambar 3 .

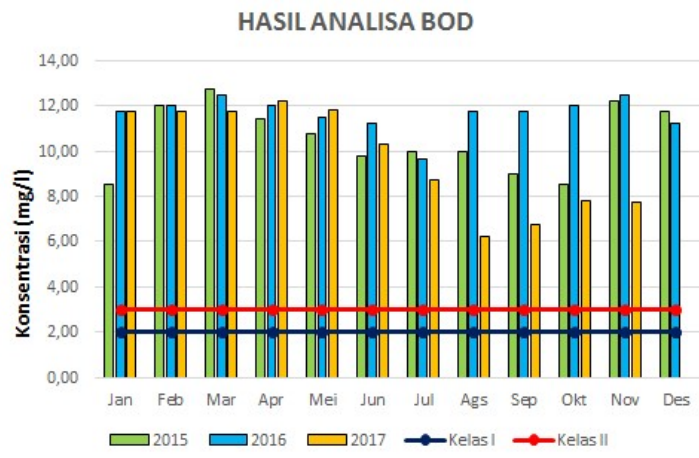

Gambar 3 : Konsentrasi BOD Air Baku di Instalasi Ngagel PDAM Surya Sembada Surabaya Dari Tahun 2018 - Tahun 2017.

Baku mutu konsentrasi BOD maksimum untuk peruntukan air kelas 2 adalah 3,0 mg/l. Dari Gambar 3 tersebut dapat dilihat bahwa konsentrasi BOD di Intake Ngagel sepanjang tahun darin tahun 2015-2017 sudah melampaui baku mutu air kelas 2 .

\subsubsection{Konsentrasi Amoniak}

Konsentrasi Amoniak dari tahun 2015 sampai dengan tahun 2017 berkisar antara 0,09 $\mathrm{mg} / \mathrm{l}$ sampai dengan $1,87 \mathrm{mg} / \mathrm{l}$. Konsentrasi amoniak rata-rata bulanan tahun 2015 sampai dengan tahun 2017 masing-masing adalah 0,45 $\mathrm{mg} / \mathrm{l}, 0,94 \mathrm{mg} / \mathrm{l}$ dan 1,27 mg/l. Grafik Amoniak rata-rata bulanan Intake IPA Ngagel PDAM Surya Sembada Surabaya Tahun 2015-2017 dapat dilihat pada Gambar 4. Baku mutu konsentrasi Amonia untuk air kelas 1 adalah 0,5 $\mathrm{mg} / \mathrm{l}$. Amoniak di dalam air sangat beraksi dengan senyawa Khlor membetuk senyawa khloramine dengan reaksi sebagai berikut :

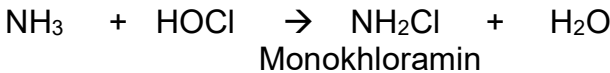

$$
\begin{aligned}
& \mathrm{NH}_{2} \mathrm{Cl}+\mathrm{HOCl} \rightarrow \mathrm{NHCl}_{2}+\mathrm{H} 2 \mathrm{O} \\
& \text { Dikhloramin } \\
& \mathrm{NHCl}_{2}+\mathrm{HOCl} \rightarrow \mathrm{NCl}_{3}+\mathrm{H} 2 \mathrm{O} \\
& \text { Trikhloramin }
\end{aligned}
$$

Perbandingan ketiga bentuk khloramin itu sangat tergantung pada $\mathrm{pH}$ air. Monokhloramin lebih dominan pada $\mathrm{pH}>8,5$. Monokhloramin dan Dikhloramin keduanya ada pada $\mathrm{pH}$ antara 4,5 dan 8,5 dan Trikhloramin terbentuk pada pada $\mathrm{pH}<4,5$. Monokhloramin merupakan zat yang dominan yang terbentuk pada suasana $\mathrm{pH}$ yang ada dalam proses pengolahan air $(\mathrm{pH}=6-9)$. $\mathrm{Di}$ dalam proses pengolahan air minum diharapkan hanya terbentuk monokhloramin, karena dikhloramin dan trikhlor-amin menimbulkan rasa yang kurang enak pada air .

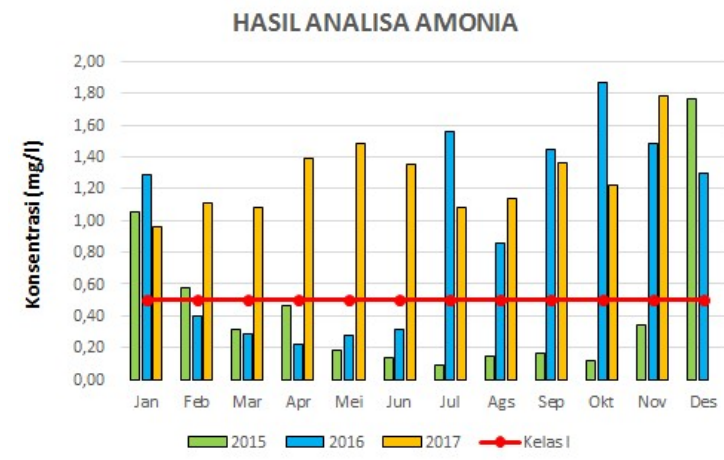

Gambar 4 : Konsentrasi Amoniak Air Baku di Instalasi Ngagel PDAM Surya Sembada

Surabaya Dari Tahun 2018 - Tahun 2017.

Untuk air murni, dosis khlorin $1 \mathrm{mg} / \mathrm{l}$ menghasilkan residu khlorin $1 \mathrm{mg} / \mathrm{l}$. Namun apabila terdapat amonia di dalam air, maka senyawa khlor dapat berekasi dengan amonia membentuk khloramine dan akan mencapai puncak (pembentukan terutama monokhloramine), pada perbandingan khlorin dengan amonia antara $4: 1$ dan 6:1, kemudian menurun hingga minimum yang disebut breakpoint. Breakpoint saat khloramin dioksidasi menjadi gas nitrogen, terjadi apabila perbandingan khlorin dengan amonia- $\mathrm{N}$ antara $7,5: 1$ dan 11 : 1 , seperti terlihat pada persamaan reaksi berikut (Bitton ; 1994).

$2 \mathrm{NH}_{3}+3 \mathrm{HOCl} \rightarrow \mathrm{N}_{2}+3 \mathrm{H}_{2} \mathrm{O}+3 \mathrm{HCl}$

Dengan demikian, jika air baku banyak mengandung amonia maka kebutuhan senyawa Khlor untuk proses disinfeksi menjadi sanngat besar. Jika konsentrasi amoniak di dalam air baku dapat diturunkan maka kebutuhan khlor akan berkurang sehingga biaya produksi air 
minum juga menjadi lebih murah. Selain itu, jika konsentrasi amonia tinggi maka pembubuhan khlor akan menjadi besar, sehingga kemungkinan terbentuknya polutan mikro seperti trihalometan, khlorophenol dan lainnya juga semakin bersar.

Trihalometan (THM) seperti khloroform, dikhlorometan, bromodikhlorometan, dibromokhlorometan, bromoform, 1,2 dikhloroetan, dan karbon tetrakhlorida merupakan senyawa khlor yang dihasilkan akibat proses khlorinasi air. Senyawa senyawa tersebut bersifat karsinogen. Hal ini mendorong U.S EPA untuk menentukan batas kandungan maximum (MCL) THM sebesar

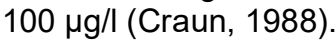

\subsubsection{Konsentrasi Nitrit}

Konsentrasi senyawa nitrit di Intake Ngagel selama tahun 2015 sampai dengan tahun 2017 dapat dilihat pada Gambar 5.

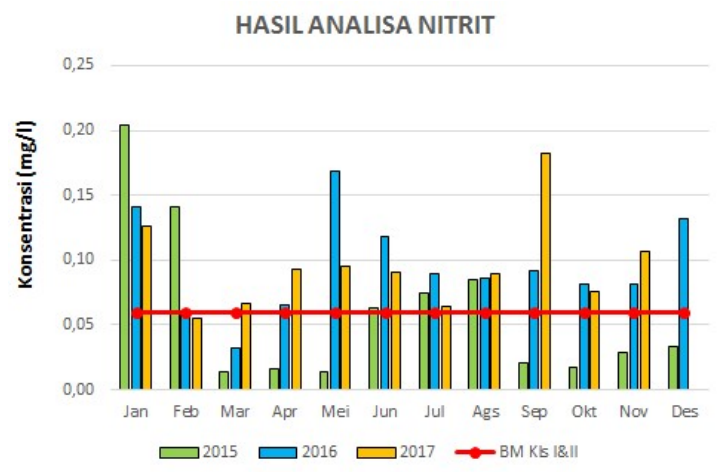

Gambar 5 : Konsentrasi Nitrit Air Baku di Instalasi Ngagel PDAM Surya Sembada Surabaya Dari Tahun 2018 - Tahun 2017

Konsentrasi nitrit di Intake Ngagel juga cenderung melebihi baku mutu air untuk kelas 1 maupun kelas 2. Senyawa nitrit merupakan senyawa antara hasil oksidasi amonium $\left(\mathrm{NH}_{4}\right)$ diperairan menjadi nitrit kemudian menjadi nitrat yang stabil. Oksidasi amoniak menjadi nitrat membutuhkan oksigen. Jika konsentrasi oksigen di dalam air rendah maka proses oksidasi amoniak tidak sempurna sehingga terbentuk senyawa nitrit.

\subsubsection{Konsentrasi Nitrat}

Konsentrasi nitrat di Intake Ngagel dari tahun 2015 sampai dengan tahun 2017 secara keseluruhan masih rendah dam masih memenuhi baku mutu untuk peruntukan air kelas 1 . Konsentrasi Nitrat di Intake Ngagel selama tahun 2015 - 2017 hampir seluruhnya masih dibawah $2,0 \mathrm{mg} / \mathrm{l}$. Konsentrasi senyawa nitrat di Intake Ngagel selama tahun 2015 sampai dengan tahun 2017 dapat dilihat pada Gambar 6.

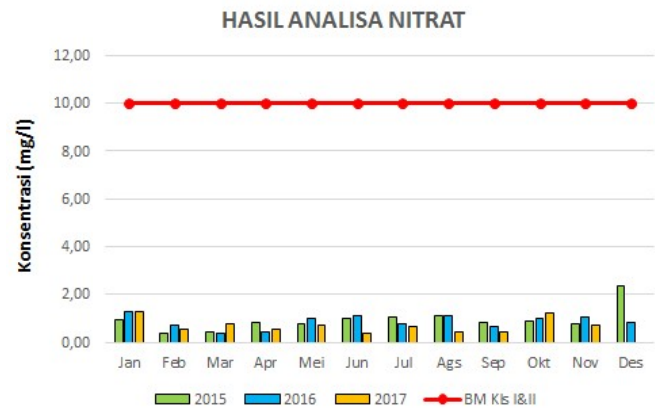

Gambar 6 : Konsentrasi Nitrat Air Baku di Instalasi Ngagel PDAM Surya Sembada

Surabaya Dari Tahun 2018 - Tahun 2017.

\subsubsection{Konsentrasi Deterjen}

Konsentrasi senyawa deterjen di Intake Ngagel selama tahun 2015 sampai dengan tahun 2017 dapat dilihat pada Gambar 7.

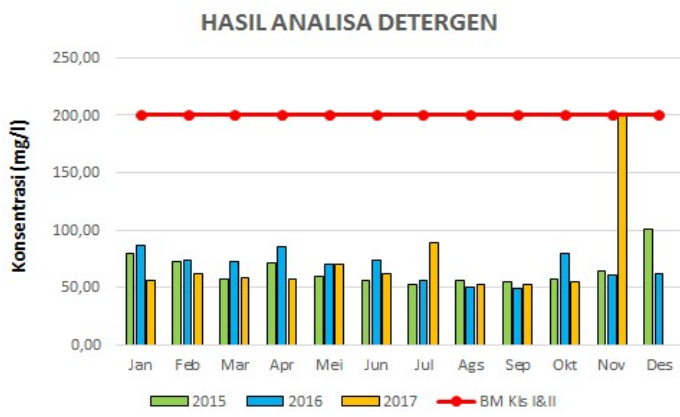

Gambar 7: Konsentrasi Detergen Air Baku di Instalasi Ngagel PDAM Surya Sembada

Surabaya Dari Tahun 2018 - Tahun 2017.

Untuk senyawa deterjen secara umum juga relatif rendah dan masih memenuhi baku mutu air kelas 2 maupun kelas 1 . Konsentrasi deterjen di Intake Ngagel selama tahun 20152017 hampir seluruhnya masih dibawah 200 $\mu \mathrm{mg} / \mathrm{l}$ atau $0,2 \mathrm{mg} / \mathrm{l}$.

\subsubsection{Konsentrasi Oksigen Terlarut (DO)}

Untuk air kelas 1 yakni peruntukan untuk air baku air minum, baku mutu konsentrasi DO mimimaal adalah $6 \mathrm{mg} / \mathrm{l}$, sedangkan untuk air kelas 2 yakni untuk peruntukan perikanan dan pertatian konsentrasi DO minumal adalah $4 \mathrm{mg} / \mathrm{l}$. Konsentrasi DO Intake Ngagel selama tahun 2015 sampai dengan tahun 2017 secara keseluruhan rata-rata masih di bawah $4 \mathrm{mg} / \mathrm{l}$. Konsentrasi senyawa oksigen terlarut (DO) di Intake Ngagel selama tahun 2015 sampai dengan tahun 2017 dapat dilihat pada Gambar 8. 
HASIL ANALISA DO

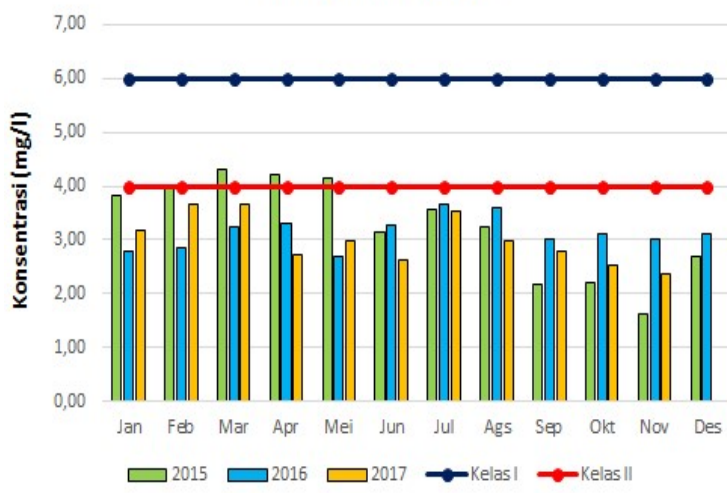

Gambar 8 : Konsentrasi Oksigen Terlarut Air

Baku di Instalasi Ngagel PDAM Surya Sembada

Surabaya Dari Tahun 2015 - Tahun 2017.

\subsubsection{Keasaman Air (pH)}

pH air di Intake Ngagel selama tahun 2015 sampai dengan tahun 2017 dapat dilihat pada Gambar 9. $\mathrm{pH}$ air di Intake Ngagel secara keseluruhan masih memenuhi baku mutu air kelas 2 maupun kelas 1 , seluruhnya masih normal yakni berkisar antara $\mathrm{pH} 7$ - 8 .

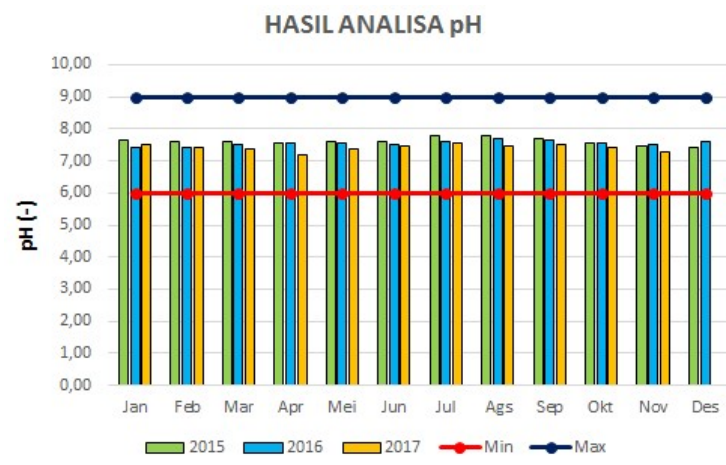

Gambar 9: pH Air Baku di Instalasi Ngagel PDAM Surya Sembada Surabaya Dari Tahun 2015 - Tahun 2017.

\subsubsection{Konsentrasi Bakteri Coli dan Fecal Coli}

Berdasarkan Nomor 82 Tahun 2001, untuk air kelas yakni untuk peruntukan air air minum, baku mutu Fecal Coliform maksimum adalah $100 \mathrm{jml} / 100 \mathrm{ml}$, sedangkan untuk kelas II adalah $1000 \mathrm{jml} / 100 \mathrm{ml}$. Baku mutu total Coliform untuk air kelas I adalah $1000 \mathrm{jml} / 100 \mathrm{ml}$ dan baku mutu untuk air kelas II adalah 5000 jml/100 ml. Konsentrasi total bakteri coliform dan fecal coliform di Intake Ngagel selama tahun 2015 sampai dengan tahun 2017 dapat dilihat pada Gambar 10 dan Gambar 11.

Secara keseluruhan konsentrasi total bakteri coliform maupun fecal coliform sudah melebihi baku mutu air kelas I maupun air kelas II. Dengan tingginya kandungan bakteri coli di dalam air baku, maka konsumsi Khlor untuk proses disinfeksi akan bertambah besar.

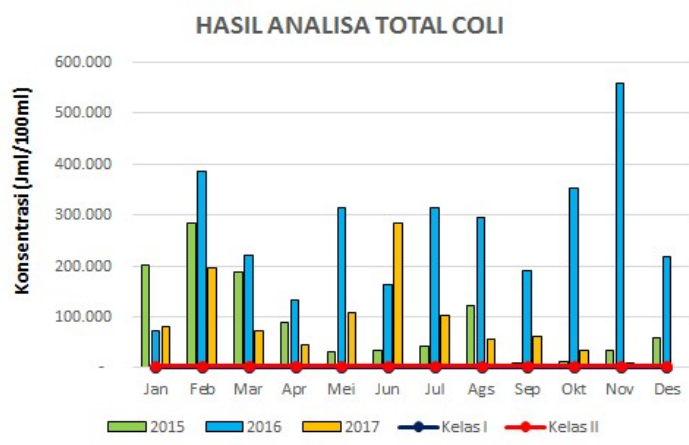

Gambar 10 : Konsentrasi Coliform Air Baku di Instalasi Ngagel PDAM Surya Sembada Surabaya Dari Tahun 2015 - Tahun 2017.

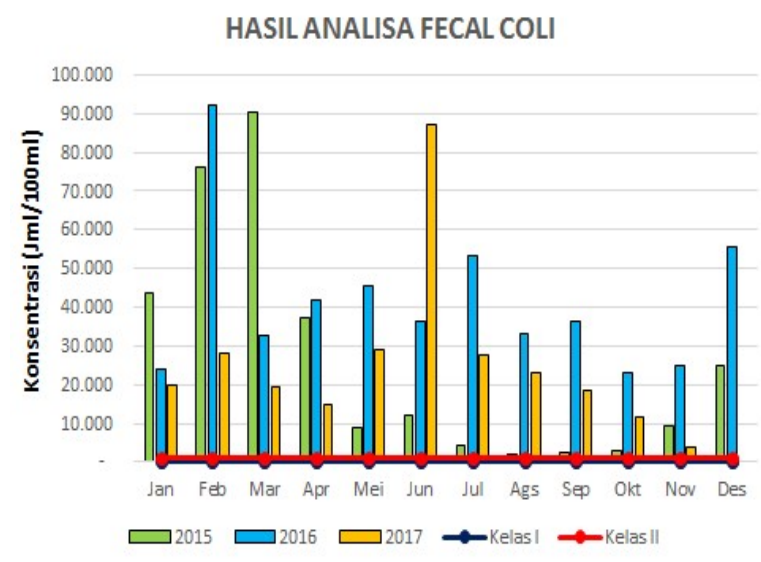

Gambar 11: Konsentrasi Fecal Coli Air Baku di Instalasi Ngagel PDAM Surya Sembada Surabaya Dari Tahun 2015 - Tahun 2017.

\subsection{Status Mutu}

Setelah dihitung menggunakan prosedur di atas, maka diperoleh status mutu Sungai Surabaya pada Intake Ngagel dibandingkan dengan baku mutu air kelas I dan II, yang dapat dilihat pada Gambar 12 msampai dengan Gambar 14.

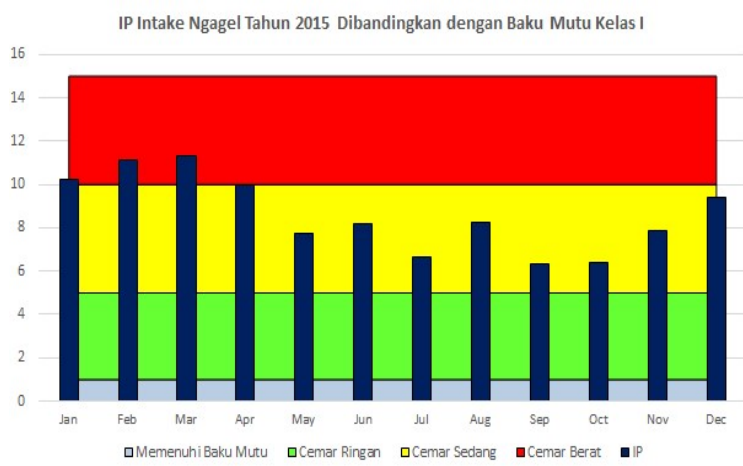




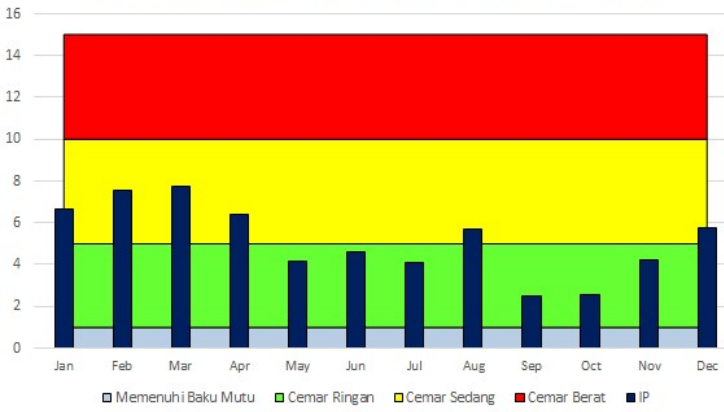

Gambar 12: Indeks Pencemaran (IP) Air Baku di Instalasi Ngagel PDAM Surya Sembada Surabaya Tahun 2015.

Grafik tersebut merupakan status mutu intake ngagel dari tahun 2015 hingga 2017 dibandingkan dengan baku mutu air kelas I dengan menggunakan metode perhitungan indeks pencemaran.

Klasifikasi mutu air (kelas air) merupakan peringkat kualitas air yang dinalai masih layak untuk dimanfaatkan bagi peruntukan tertentu. Peruntukan air kelas I dapat digunakan untuk air baku air minum, dan atau dan atau peruntukan lain yang mempersyaratkan mutu air yang sama dengan kegunaan tersebut.

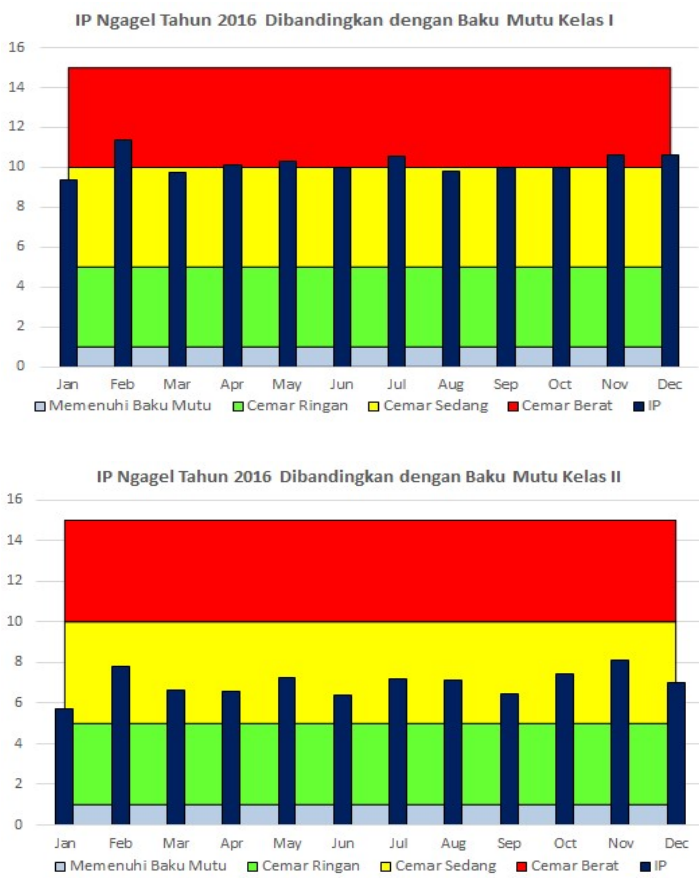

Gambar 13 : Indeks Pencemaran (IP) Air Baku di Instalasi Ngagel PDAM Surya Sembada

Surabaya

Tahun 2016.
IP Ngagel Tahun 2017 Dibandingkan dengan Baku Mutu Kelas I

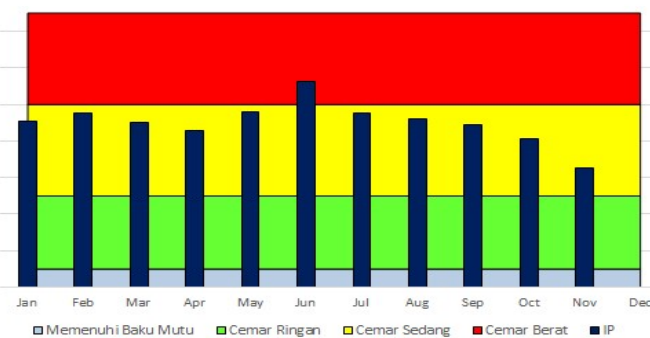

IP Ngagel Tahun 2017 Dibandingkan dengan Baku Mutu Kelas II

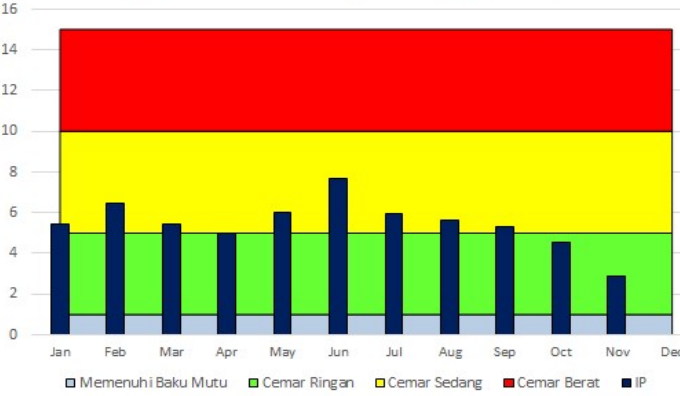

Gambar 14 : Indeks Pencemaran (IP) Air Baku di Instalasi Ngagel PDAM Surya Sembada Surabaya Tahun 2017

Dari Gambar 12 - 14 tersebut, dapat diketahui bahwa tingkat pencemaran air di Intake Ngagel tahun 2015 - 2017 tergolong dalam pencemaran sedang hingga cemar berat. Parameter yang paling potensial menyebabkan tingkat cemaran tersebut adalah DO, COD, BOD, dan kandungan organik dalam sungai tersebut melebihi baku mutu air kelas I berdasarkan PP No 82 tahun 2001. Dari tahun 2015 hingga 2016, terjadi peningkatan tingkat pencemaran, tetapi pada tahun 2017 tingkat cemaran cenderung sedikit mengalami penurunan dibandingkan dengan 2 (dua) tahun sebelumnya.

\subsection{Senyawa Hasil Samping Proses Disinfeksi (disinfection by-products)}

Sumber air yang terkontaminasi atau tercemar disebabkan oleh berbagai kegiatan, seperti mandi, cuci, memasak, manufaktur ataupun disebabkan oleh kegiatan industri. Zat polutan yang ditemukan dalam air yang tercemar sangat bervariasi termasuk logam, zat organik, garam, patogen, amoniak, pestisida, serta bahan kima farmasi.

Adanya bahan polutan organik alami (nartural organic matter) dan bahan organik terlarut (dissolved organic matter) dalam sumber air adalah prekursor utama untuk pembentukan senyawa hasil samping disinfeksi di dalam air minum. Pembentukan senyawa hasil samping disinfeksi terjadi melalui reaksi senyawa polutan organik dengan bahan kimia disinfektan 
khususnya klorin selama proses klorinasi air. senyawa organik alami adalah campuran kompleks dari senyawa organik yang berasal dari peluruhan vegetasi dan material hewan (Hua\&Yeats ; 2010). Senyawa organik terlarut meliputi banyak senyawa, seperti karbohidrat, zat humat, asam karboksilat, asam hidrofilik dan asam amino (Thurman ; 1985). Senyawasenyawa ini telah diidentifikasi sebagai mutagens genotoksik, yang dapat menjadi racun bagi manusia dan kehidupan akuatik (Zhang. et al. ; 2013). Berdasarkan studi epidemiologi, senyawa hasil samping disinfeksi terkait dengan peningkatan risiko kanker kandung kemih dan usus besar dan kelahiran prematur dan mati lahir (Bove. et al. ; 2007 \& Villanueva. et al. ; 2007). Selain itu, paparan jangka panjang oleh senyawa hasil samping disinfeksi dapat meningkatkan efek merugikan potensial pada sistem reproduksi (Richardson. et al. ; 2007).

Disinfeksi adalah proses penting dalam penghilangan mikroorganisme patogen dalam air minum. Untuk memastikan keamanan air minum, desinfeksi adalah merupakan proses yang sangat penting Idi dalam proses pengolahan air minum (Crittenden et al. ; 2012 \& Ohar ; 2014). Namun, sejak tahun 1970-an, telah diakui bahwa desinfeksi dapat menghasilkan produk sampingan yang berbahaya dan menyebabkan masalah kesehatan (Hua\&Yeats ; 2010). Ada 600-700 jenis senyawa hasil samping proses disinfeksi yang dihasilkan ketika zat organik yang terjadi secara alami berinteraksi dengan senyawa halogen selama proses pengolahan air (James et al. ;2015 , Krasner S.W ; 2009 \& Nieuwenhuijsen ; 2009). Reaksi senyawa khlorin dengan polutan organik dalam air baku menghasilkan pembentukan trihalometan (THMs), haloacetonitril, asam haloacetat dan senyawa kimia lainnya (Platikanov ; 2012). Senyawa yang paling umum dari hasil samping proses disinfeksi mengguakan khlorin adalah trihalometan (Krasner et al. ; 2006), yang meliputi kloroform $\left(\mathrm{CHCl}_{3}\right)$, bromo-dikhlorometan $\left(\mathrm{CHCl}_{2} \mathrm{Br}\right)$, dibromokhloro-metan ( $\mathrm{CHClBr} 2)$ dan bromoform $\left(\mathrm{CHBr}_{3}\right)$. Paparan trihalometan telah terbukti mempunyai pengaruh yang burauk terhadap reproduksi dan menyebabkan kanker pencernaan dan memiliki dampak negatif pada sistem genitourinari (Richardson. et al. ; 2007, Nieuwenhuijsen ; 2009 \& Grellier et al. ; 2010).

\subsection{Alternatif Teknologi Peningkatan Kualitas Air Baku}

Penelitian tentang peningkatan kualitas air baku air minum Di Indonesia telah dilakukan oleh beberapa peneliti. Penelitian tentang penghilangan senyawa organik di dalam air baku dengan menggunakan proses biofilter dengan media plastik tipe sarang tawon telah dilakukan oleh Said dan Hidayati tahun 2000. Dari hasil penelitian tersebut dapat dilihat bahwa dengan kondisi waktu tinggal hidrolis 1 jam efisiensi penghilangan zat organik 30,92 \% untuk waktu tinggal 2 jam efisiensi sebesar 45,70 \% sedangkan pada waktu tinggal 3 jam sebesar $53,89 \%$ dan pada waktu tinggal 4 jam sebesar $64,27 \%$. Dari hasil penelitian Said dan Hidayati tersebut didapatkan hasil hubungan antara beban organik dan efisiensi penghilangan zat orgaik yakni semakin besar beban organik di dalam reaktor biofilter maka efisiensi penyisihan menjadi berkurang. Said dan Tresnaway (2001) telah melakukan penelitian dengan mengoperasikan secara kontinyu satu reaktor biofilter tercelup menggunakan media palstik tipe sarang tawon dengan, ukuran $210 \mathrm{cmx} 30 \mathrm{cmx}$ $59 \mathrm{~cm}$, volume total 371,7 liter. Efisiensi penurunan amoniak berdasarkan variasi waktu tinggal hidrolis 1-3 jam berkisar antara 48,74\% $73.59 \%$. Pada pengolahan dengan pengkondisian waktu tinggal hidrolis 1 jam efisiensi penurunan sebesar $48.74 \%$, untuk waktu tinggal 2 jam menunjukkan efisiensi sebesar $67.98 \%$, untuk waktu tinggal 3 jam efisiensi sebesar 73,59 \%.

Said dan Nugroho (2012) telah melakukan penelitian untuk meningkatkan kualitas air baku PAM Taman Kota dengan menggunakan proses biofiltrasi serta mengkaji kinerja reaktor biofilter dengan media plastik tipe sarang tawon terhadap penurunan konsentrasi zat organik, amoniak, deterjen (MBAS), besi, mangan serta padatan tersuspensi. Dari hasil penelitan tersebut disimpulkan bahwa efisisensi penghilangan polutan di dalam proses biofiltrasi sangat dipengaruhi oleh waktu tinggal di dalam reaktor biofilter. Makin pendek waktu tinggal maka efisiensi penghilangan semakin rendah. Untuk mendapatkan kualitas air olahan agar memenuhi standar kualitas air baku air minum maka waktu tinggal di dalam reaktor biofilter minimal 1 jam. Tingginya konsentrasi TSS dan turbidity yang sebagian besar adalah lumpur tanah yang terbawa air hujan menyebabkan lapisan biomassa pada media sarang tawon tertutup. Hal ini menyebabkan effisiensi pengolahan menurun. Kemampuan degradasi polutan akan berkurang dengan adanya lumpur tanah yang mengendap di dalam media biofilter. Untuk itu dalam aplikasinya untuk skala penuh perlu dilengkapi dengan pre-sedimentasi untuk mengendapkan lumpur tanah yang dapat mengganggu proses biodegradasi senyawa polutan di dalam reaktor biofilter.

Berdasarkan beberapa hasil penelitian tersebut di atas, maka salah satu alternatif untuk meningkatkan kualitas air baku di Intake Ngagel yang yang diambil dari Sungai Surabaya adalah dengan menggunakan sistem biofilter. 
Sistem biofilter dirancang agar dapat diintegrasikan dengan unit IPA konvensional sebagai pengolahan pendahuluan (Pretreatment). Konsep umum proses peningkatan kualitas air baku dengan sistem biofilter dan proses IPA konvensional dapat dilihat seperti pada Gambar 15.

Air baku dialirkan ke bak pengendap tipe Lamella yang dilengkapi dengan peralatan pembubuhan bahan kimia koagulan.

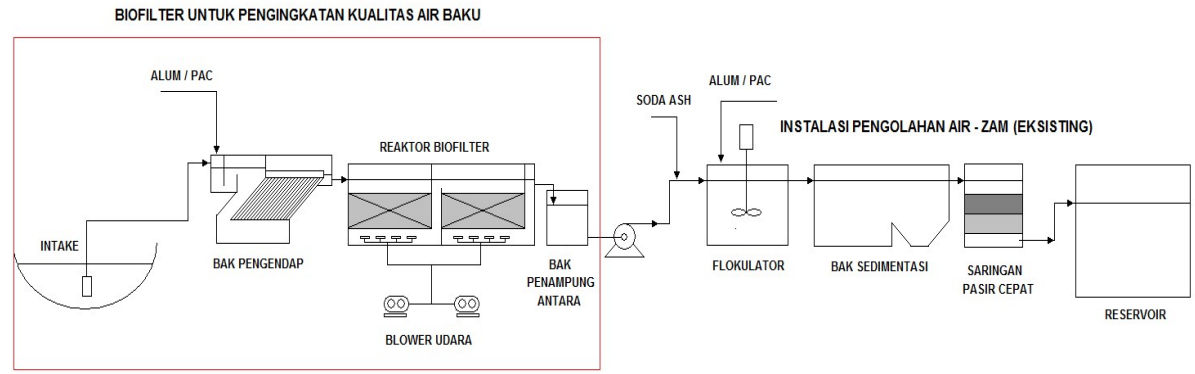

Gambar 15 : Konsep Umum Proses Peningkatan Kualitas Air Baku Dengan Sistem Biofilter Dan Proses IPA Eksisting.

Pembubuhan bahan kimia koagulan dilakukan apabila konsetarsi TSS air baku tinggi terutama pada saat musim hujan, dan pembubuhan soda ash dilakukan jika $\mathrm{pH}$ air baku rendah. Dari bak pengendap air dialirkan ke reaktor biofilter sambil diaerasi atau dihembus dengan udara. Air limpasan dari reaktor biofilter ditampung di bak penampung antara, selanjutnya akan digunakan sebagai air baku untuk Unit IPA konvensional. Reaktor biofilter harus dilengkapi mekanisme pembuangan lumpur.

Dengan proses biofiltrasi konsentrasi polutan organik, amoniak, detergen, padatan tersuspensi, zat besi, mangan akan dapat diturunkan sehingga konsumsi bahan kimia khususnya koagulan dan khlor untuk pengolahan air minum menjadi berkurang. Dengan demikian biaya produksi pengolahan air juga akan menjadi berkurang. Dengan semakin rendahnya konsentrasi amoniak di dalam air baku, maka penggunaan khor juga akan semakin sedikit, sehingga kemungkinan terjadinya senyawa hasil samping khlorinasi misalnya trihalometan juga semakin kecil.

\section{KESIMPULAN DAN SARAN} disimpulkan :

Dari hasil penelitian diatas dapat

a. Jika dibandingkan dengan baku peruntukan air sesuai dengan PP No.82 Tahun 2001 tentang Pengelolaan Kualitas Air dan Pengendalian Pencemaran Air, maka air intake Ngagel masuk dalam kriteria peruntukan air Kelas 2, yakni air yang peruntukannya dapat digunakan untuk prasarana/sarana rekreasi air, pembudidayaan ikan air tawar, peternakan, air untuk mengairi pertanaman, dan atau peruntukkan lain yang mempersyaratkan mutu air yang sama dengan kegunaan tersebut dengan konsentrasi COD maksimum $25 \mathrm{mg} / \mathrm{l}$.

b. Untuk peruntukan air Kelas 1, yakni air yang peruntukannya dapat digunakan untuk air baku air minum, dan atau peruntukan lain yang mempersyaratkan mutu air yang sama dengan kegunaan tersebut, konsentrasi COD maksimum adalah $10 \mathrm{mg} / \mathrm{l}$. Jika dibandingkan dengan mutu air kelas 1, maka konsentrasi COD di intake Ngagel hampir sepanjang tahun sudah melampaui baku mutu air kelas 1.

c. COD rata-rata tahun 2015, 2016 dan 2017 masing-masing sebesar 13,7 mg/l, 14,93 mg/l dan 16,56 mg/l.

d. Konsentrasi Zat Organik $\left(\mathrm{KMnO}_{4}\right)$, dari tahun 2015 sampai dengan tahun 2017 berkisar antara 8,05 mg/l - 24,07 mg/l, dan Jika dibandingkan dengan baku peruntukan air sesuai dengan PP No.82 Tahun 2001 tentang Pengelolaan Kualitas Air dan Pengendalian Pencemaran Air, maka konsentrasi zat organik air intake Ngagel masuk dalam kriteria peruntukan air Kelas 2.

e. Konsentrasi BOD rata-rata bulanan Intake IPA Ngagel PDAM Surya Sembada Surabaya Tahun 2015-2017 berkisar antara 6,25 mg/l $12,50 \mathrm{mg} / \mathrm{l}$, dari tahun 2015-2017 sudah melampaui baku mutu air kelas 2 .

f. Konsentrasi Amoniak dari tahun 2015 sampai dengan tahun 2017 berkisar antara 0,09 mg/l sampai dengan 1,87 mg/l. Konsentrasi amoniak rata-rata tahun 2015 sampai dengan tahun 2017 cenderung meningkat yakni masing-masing adalah 0,45 mg/l, 0,94 mg/l dan $1,27 \mathrm{mg} / \mathrm{l}$. 
g. Berdasarkan perhitungan Indeks Pencemaran (IP), status mutu air di Intake Ngagel tahun 2015 - 2017 tergolong dalam pencemaran sedang hingga cemar berat. Parameter yang paling potensial menyebabkan tingkat cemaran tersebut adalah DO, COD, BOD, dan kandungan organik dalam sungai tersebut melebihi baku mutu air kelas 1.

h. Salah satu alternatif untuk meningkatkan kualitas air baku di Intake Ngagel yang yang diambil dari Sungai Surabaya adalah dengan menggunakan sistem biofilter.

i. Dengan proses biofiltrasi konsentrasi polutan organik, amoniak, detergen, padatan tersuspensi, zat besi, mangan akan dapat diturunkan sehingga konsumsi bahan kimia khususnya koagulan dan khlor untuk pengolahan air minum menjadi berkurang. Dengan demikian biaya produksi pengolahan air juga akan menjadi berkurang. Dengan semakin rendahnya konsentrasi amoniak di dalam air baku, maka penggunaan khor juga akan semakin sedikit, sehingga kemungkinan terjadinya senyawa hasil samping khlorinasi misalnya trihalometan juga semakin kecil

\section{PERSANTUNAN}

Penulis menyampaikan terima kasih kepada Perusahaan Umum (PERUM) Jasa Tirta I dan PDAM Surya Sembada Surabaya atas bantuan dan fasilitasinya dalam melakukan kajian penelitian dalam rangka rencana peningkatan kualitas air baku PDAM Surabaya. Terimakasih juga disampaikan kepada Direktur Pusat Teknologi Lingkungan yang telah mendukung terlaksananya kegiatan ini.

\section{DAFTAR PUSTAKA}

1. Rahmanizar Maksum Yunianto dan Udisubakti Ciptomulyono., Skrpsi : Kajian Life Cycle Assessment (LCA) Untuk Perbaikan Produksi Air Bersih Instalasi Pengolahan Air Minum (IPAM) Ngagel II Pdam Surabaya Dengan Pendekatan Analytic Network Process (ANP). Jurusan Teknik Industri, Institut Teknologi Sepuluh Nopember (ITS) Surabaya. Kampus ITS Sukolilo Surabaya 60111.

2. Annonim., Porfil Perusahaan-PDAM Surya Sembada Kota Surabaya.https://www.pdamsby.go.id/page.php?get=sejarah_status_pdam \&bhs=1. Diakases 13 Desember 2018.

3. Priyono T.S.C., E. Yuliani, R. W. Sayekti. “ Studi Penentuan Status Mutu Air Di Sungai Surabayauntuk Keperluan Bahan Baku Air Minum".Jurnal Teknik Pengairan, Volume 4, Nomor 1 ,Me i2013, hlm 53-60..
4. Annonim, 2012. Profil Keanekaragaman Hayati Kota Surabaya 2012. BLH kota Surabaya.

5. Annonim, 2017. Pembangunan Model Test Biofilter Untuk Meningkatkan Kualitas Air Baku Yang Diambil Dari Sungai Surabaya. PERUM JASA TIRTA I. JI. Surabaya No. 2A Malang -Jawa Timur 65145.

6. Sheftiana, Sarach, el all. 2017. "Penentuan Status Mutu Air Sungai Berdasarkan Metode Indeks Pencemaran Sebagai Pengendalian Kualitas Lingkungan (Studi Kasus : Sungai Gelis, Kabupaten Kudus, Jawa Tengah)". Jurnal Teknik Lingkungan, Vol. 6, No. 1 (2017).

7. Menteri Lingkungan Hidup Republik Indonesia. 2003. Keputusan Menteri Lingkungan Hidup Nomor : 115 Tahun 2003 tentang Pedoman Penentuan Status Mutu Air, Jakarta

8. Nemerow, N.L. and Sumitomo, H. 1970. Benefits of Water Quality Enhancement. Report No. 16110 DAJ, prepared for the U.S. Environmental Protection Agency. December 1970. New York.

9. Nemerow, Nelson Leonard., "Scientific Stream Pollution Analysis". McGraw-Hill series in water resources and environmental engineering. (1974-12-01).

10.Annonim, 2001. PP Nomor 82 Tahun 2001 Tentang Pengendalian pencemaran Alr. Kementerian Lingkungan Hidup. Jakarta.

11.Bitton Gabriel. 1994. Wastewater Microbiology, A John Wiley \& Sons, INC., New York.

12.Craun,G.F., 1988. Surface water supplies and health. Journal American Water Works Association. 80:40-52.

13. Hua G., Yeats S.A., 2010. Control of Trihalomethanes in Wastewater Treatment. Florida Water Resources Journal. (2010)

14.Thurman E.M., 1985. Organic Geochemistry of Natural Waters, Martinus Nijhoff/Dr. W. Junk Publishers, Dordrecht, Netherlands, 1985.

15.Zhang F., Wang Y., Chu Y., Gao B., Yue Q., Yang Z., Li Q., 2013. "Reduction of organic matter and trihalomethane formation potential in reclaimed water from treated municipal wastewater by coagulation and adsorption". J. Chem. Eng. 233 (2013).

16.Bove G.E., Rogerson P.A., Vena J.E., "Case control study of the geographic variability of exposure to disinfectant byproducts and risk for rectal cancer". Int. J. Health Geogr. 6 (2007).

17.Villanueva C.M., Cantor K.P., Grimalt J.O., Malats N., Silverman D., Tardon A., GarciaClosas R., Serra C., Carrato A., CastanoVinyals G., Marcos R., Rothman N., Real F.X., Dosemeci M. , Kogevinas M., 2007. 
"Bladder cancer and exposure to water disinfection by-products through ingestion, bathing, showering, and swimming in pools". Am. J. Epidemiol. 165 (2007).

18.Richardson S.D., M.J. Plewa, E.D. Wagner, R. Schoeny, D.M. Demarini. 2007 "Occurrence, genotoxicity, and carcinogenicity of regulated and emerging disinfection byproducts in drinking water: a review and roadmap for research". Mutat. Res. 636 (2007) 178.

19. Crittenden J.C., R.R. Trussell, D.W. Hand, K.L. Howe, G. Tchobanoglous. 2012. MWH's Water Treatment: Principles and Design, third ed., John Wiley and Sons, Hoboken, NJ.

20.Ohar Z., A. Ostfeld.2014. "Optimal design and operation of booster chlorination stations layout in water distribution systems". Water Res. 58 (2014).

21.James B.B., M.E. Todd, K.S. Ratanesh, D.W. Michael, C. Saurabh.2015. "Trihalomethane exposure and biomonitoring for the liver injury indicator, alanine aminotransferase, in the United States population (NHANES 19992006)". Sci. Total Environ. 521-522.

22.Krasner S.W., Philos. Trans. 2009. "The formation and control of emerging disinfection by-products of health concern". A Math. Phys. Eng. Sci. 367.

23.Nieuwenhuijsen M.J., D. Martinez, J. Grellier, J. Bennett, N. Best, N. Iszatt, M. Vrijheid, M.B. Toledano. 2009. "Chlorination disinfection byproducts in drinking water and congenital anomalies: review and meta-analyses". Environ. Health Perspect. 117.

24.Platikanov S., J. Martin, R. Tauler. 2012. Linear and non-linear chemometric modeling of THM formation in Barcelona's water treatment plant. Science of The Total Environment. 432.

25.Krasner S.W., H.S. Weinberg, S.D. Richardson, S.J. Pastor, R. Chinn, M.J. Sclimenti, G.D. Onstad, A.D. Thruston. 2006. "Occurrence of a new generation of disinfection byproducts". Environ. Sci. Technol. 40.

26.Grellier J., J. Bennett, E. Patelarou, R.B. Smith, M.B. Toledano, L. Rushton, D.J. Briggs, M.J. Nieuwenhuijsen.2010. "Exposure to disinfection by-products, fetal growth, and prematurity: a systematic review and metaanalysis". Epidemiology 21 (3).

27.Said, N.I., dan S.M. Hidayati. 2000. "Penghilangan Polutan Organik Di dalam Air Baku Air Minum Dengan Proses Biofilter Tercelup Menggunakan Media Plastik Sarang Tawon". Jurnal Sains dan Teknologi Indonesia Volume 2 Nomor : 9 Th 2000. BPPT, Jakarta.
28.Said, N.I., R. Tresnaway. 2001. "Penghilangan Amoniak Di dalam Air Baku Air Minum Dengan Proses Biofilter Tercelup Menggunakan Media Plastik Sarang Tawon". Jurnal Teknologi Lingkungan Volume 2, Nomor 2, Mei 2001. Direktorat Teknologi Lingkungan, BPPT. Jakarta.

29.Said, N.I., R. Nugroho., 2012. “ Evaluasi Kinerja Sistem Biofiltrasi Untuk Instalasi Pengolahan Air Minum". Jurnal Hidrosfir Indonesia, Vol 7, No.2, 2012. 
Tabel 1 : Hasil Analisa Kualitas Air Baku Rata-Rata Bulanan Instalasi Penjernihan Ngagel Tahun 2015.

\begin{tabular}{|c|c|c|c|c|c|c|c|c|c|c|c|c|c|c|}
\hline \multirow{2}{*}{ No } & \multirow{2}{*}{ Parameter } & \multirow{2}{*}{ Satuan } & \multicolumn{12}{|c|}{ Bulan ke- } \\
\hline & & & Jan & Feb & Mar & Apr & May & Jun & Jul & Aug & Sep & Oct & Nov & Dec \\
\hline 1 & Suhu & ${ }^{\circ} \mathrm{C}$ & 26,89 & 26,65 & 26,98 & 26,57 & 26,75 & 27,40 & 27,20 & 25,31 & 26,12 & 26,79 & 27,32 & 26,81 \\
\hline 2 & Kekeruhan & Skala NTU & 157,41 & 245,87 & 224,39 & 221,74 & 49,85 & 20,93 & 22,46 & 14,41 & 11,19 & 10,33 & 10,31 & 154,69 \\
\hline 3 & Warna & Pt-Co & 240,63 & 317,46 & 73,99 & 117,47 & 25,44 & 22,08 & 13,11 & 16,52 & 19,14 & 8,52 & 9,03 & 57,11 \\
\hline 4 & ss & $\mathrm{mg} / \mathrm{l}$ & 168,95 & 225,21 & 222,45 & 196,90 & - & - & - & - & - & - & - & - \\
\hline 5 & $\mathrm{pH}$ & & 7,63 & 7,61 & 7,61 & 7,55 & 7,58 & 7,62 & 7,79 & 7,77 & 7,68 & 7,58 & 7,48 & 7,41 \\
\hline 6 & Alkalinitas & $\mathrm{mg} / \mathrm{l} \mathrm{CaCO}$ & 143,90 & 153,66 & 161,47 & 156,48 & 164,57 & 173,31 & 185,35 & 189,15 & 183,16 & 199,65 & 198,29 & 168,06 \\
\hline 7 & $\mathrm{CO} 2$ Bebas & $\mathrm{mg} / \mathrm{l} \mathrm{CO}_{2}$ & 6,91 & 7,43 & 7,97 & 8,98 & 8,73 & 8,62 & 6,08 & 6,46 & 7,71 & 12,41 & 13,14 & 13,08 \\
\hline 8 & DO & $\mathrm{mg} / \mathrm{lo}_{2}$ & 3,83 & 4,03 & 4,32 & 4,22 & 4,15 & 3,14 & 3,55 & 3,24 & 2,18 & 2,19 & 1,64 & 2,69 \\
\hline 9 & Nitrit & $\mathrm{mg} / \mathrm{l} \mathrm{NO} \mathrm{z}_{z}-\mathrm{N}$ & 0,20 & 0,14 & 0,01 & 0,02 & 0,01 & 0,06 & 0,07 & 0,08 & 0,02 & 0,02 & 0,03 & 0,03 \\
\hline 10 & Amonia & $\mathrm{mg} / \mathrm{l} \mathrm{NH}_{3}-\mathrm{N}$ & 1,06 & 0,58 & 0,32 & 0,46 & 0,18 & 0,14 & 0,09 & 0,15 & 0,17 & 0,12 & 0,34 & 1,77 \\
\hline 11 & Tembaga & $\mathrm{mg} / \mathrm{l} \mathrm{Cu}$ & 0,84 & 0,85 & 0,63 & 0,82 & 0,26 & 0,19 & 0,14 & 0,18 & 0,27 & - & - & - \\
\hline 12 & Phospat & $\mathrm{mg} / \mathrm{l} \mathrm{PO}_{4}$ & 0,21 & 0,18 & 0,22 & 0,18 & 0,15 & 0,19 & 0,18 & 0,22 & 0,20 & 0,24 & 0,22 & 0,24 \\
\hline 13 & $\begin{array}{l}\text { Besi } \\
\text { Krom }\end{array}$ & $\mathrm{mg} / \mathrm{l} \mathrm{Fe}$ & 0,05 & 0,15 & 0,06 & 0,82 & 0,22 & 0,15 & 0,21 & 0,19 & 0,07 & - & - & - \\
\hline 14 & Heksavalen & $\mathrm{mg} / \mathrm{l} \mathrm{Cr}{ }^{5+}$ & 0,00 & 0,00 & 0,00 & 0,01 & 0,00 & 0,00 & 0,00 & 0,00 & 0,00 & 0,00 & $\mathrm{ttd}$ & 0,01 \\
\hline 15 & Mangan & $\mathrm{mg} / \mathrm{l} \mathrm{Mn}$ & - & - & - & 0,16 & 0,09 & 0,11 & & - & - & - & - & - \\
\hline 16 & Seng & $\mathrm{mg} / \mathrm{l} \mathrm{Zn}$ & - & - & - & 0,03 & 0,01 & 0,00 & & - & - & - & - & - \\
\hline 17 & Timbal & $\mathrm{mg} / \mathrm{l} \mathrm{Pb}$ & - & - & - & 0,01 & 0,02 & 0,02 & & - & - & - & - & - \\
\hline 18 & $C O D$ & $\mathrm{mg} / \mathrm{l} \mathrm{O}_{2}$ & 15,20 & 15,00 & 14,67 & 12,44 & 14,00 & 12,00 & 12,00 & 12,10 & 10,00 & 10,86 & 15,42 & 14,35 \\
\hline 19 & Detergen & $\mu \mathrm{g} / \mathrm{lt}$ MBAS & 79,05 & 72,12 & 56,68 & 71,04 & 59,83 & 55,42 & 52,27 & 55,42 & 54,91 & 57,63 & 63,99 & 100,79 \\
\hline 20 & $\mathrm{DHL}$ & $\mu \mathrm{S} / \mathrm{cm}$ & 499,50 & 414,00 & 416,50 & 437,20 & 529,50 & 570,50 & 538,00 & 588,00 & 579,20 & 573,00 & 583,50 & 497,00 \\
\hline 21 & Kesadahan & $\mathrm{mg} / \mathrm{l} \mathrm{CaCO}{ }_{3}$ & 191,20 & 189,07 & 228,38 & 223,56 & 263,90 & 267,91 & 264,43 & 238,57 & 224,45 & 215,12 & 203,54 & 192,41 \\
\hline 22 & Nitrat & 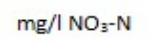 & 0,92 & 0,37 & 0,45 & 0,83 & 0,78 & 0,97 & 1,03 & 1,14 & 0,82 & 0,87 & 0,77 & 2,33 \\
\hline 23 & Silikat & $\mathrm{mg} / \mathrm{I} \mathrm{SiO}{ }_{2}-\mathrm{N}$ & 2,36 & 2,56 & 2,88 & 15,28 & 22,84 & 12,55 & 23,14 & 25,56 & 16,87 & 22,42 & 31,61 & 20,93 \\
\hline 24 & Zat Organik & $\mathrm{mg} / \mathrm{l} \mathrm{KMnO} 4$ & 19,09 & 13,21 & 15,20 & 15,82 & 10,63 & 9,18 & 12,59 & 11,73 & 11,40 & 12,06 & 11,12 & 16,42 \\
\hline 25 & $\mathrm{BOD}$ & $\mathrm{mg} / \mathrm{l} \mathrm{O}_{2}$ & 8,50 & 12,00 & 12,75 & 11,40 & 10,75 & 9,75 & 10,00 & 10,00 & 9,00 & 8,50 & 12,25 & 11,75 \\
\hline 26 & Kalsium & $\mathrm{mg} / \mathrm{l} \mathrm{CaCO} 3$ & 139,86 & 154,29 & 146,52 & 114,34 & 136,84 & 139,55 & 147,77 & 152,10 & 153,52 & 135,14 & 132,32 & 134,54 \\
\hline 27 & Magnesium & mg/l Mg & 12,48 & 14,56 & 19,89 & 25,89 & 30,61 & 31,19 & 28,35 & 25,34 & 17,23 & 19,44 & 17,31 & 14,06 \\
\hline 28 & Klorida & $\mathrm{mg} / \mathrm{l} \mathrm{cl}$ & 29,23 & 21,84 & 22,15 & 22,49 & 27,82 & 32,44 & 33,86 & 34,85 & 35,79 & 36,54 & 41,03 & 34,25 \\
\hline 29 & Sulfat & $\mathrm{mg} / \mathrm{lsO}_{4}$ & 46,24 & 40,28 & 32,13 & 34,89 & 34,67 & 22,15 & 21,51 & 56,56 & 31,41 & 28,69 & 32,76 & 43,59 \\
\hline 30 & Fluorida & $\mathrm{mg} / \mathrm{l} \mathrm{F}$ & 0,84 & 1,17 & 1,05 & 0,28 & 0,69 & 0,45 & 0,55 & 0,30 & 0,43 & 0,67 & 0,85 & 0,89 \\
\hline 31 & Arsen & $\mathrm{mg} / \mathrm{l} \mathrm{As}$ & - & - & - & - & - & - & - & - & - & - & - & - \\
\hline 32 & Kadmium & $\mathrm{mg} / \mathrm{l} \mathrm{cd}$ & - & - & - & - & - & - & - & - & - & - & - & - \\
\hline 33 & Phenol & $\mu \mathrm{g} / \mathrm{l}$ & 0,09 & 0,16 & 0,35 & 0,78 & 0,23 & 0,31 & 0,18 & 0,19 & 0,25 & 0,16 & 0,15 & 0,62 \\
\hline 34 & Total Coli & $\mathrm{Jml} / 100 \mathrm{ml}$ & 200575 & 283333 & 187750 & 88000 & 31000 & 33250 & 42750 & 120900 & 10220 & 12650 & 32750 & 58250 \\
\hline 35 & Fecal coli & $\mathrm{Jml} / 100 \mathrm{ml}$ & 43750 & 76333 & 90500 & 37400 & 9000 & 12075 & 4275 & 2050 & 2660 & 3100 & 9225 & 24675 \\
\hline 36 & Aluminium & mg/l Al & - & - & - & - & $\cdot$ & - & & - & - & - & - & - \\
\hline
\end{tabular}


Tabel 2 : Hasil Analisa Kualitas Air Baku Rata-Rata Bulanan Instalasi Penjernihan Ngagel Tahun 2016.

\begin{tabular}{|c|c|c|c|c|c|c|c|c|c|c|c|c|c|c|}
\hline \multirow{2}{*}{ No } & \multirow{2}{*}{ Parameter } & \multirow{2}{*}{ Satuan } & \multicolumn{12}{|c|}{ Bulan ke- } \\
\hline & & & Jan & $\mathrm{Feb}$ & Mar & Apr & May & Jun & Jul & Aug & Sep & Oct & Nov & Dec \\
\hline 1 & Suhu & ${ }^{\circ} \mathrm{C}$ & 27,05 & 26,93 & 27,20 & 26,94 & 27,27 & 26,79 & 27,10 & 27,06 & 27,51 & 27,40 & 27,45 & 27,25 \\
\hline 2 & Kekeruhan & Skala NTU & 121,83 & 182,26 & 182,09 & 156,48 & 89,39 & 75,32 & 51,75 & 41,84 & 44,64 & 132,72 & 100,65 & 185,30 \\
\hline 3 & Warna & Pt-Co & 52,81 & 51,88 & 41,82 & 31,74 & 54,03 & 35,43 & 20,84 & 23,82 & 39,42 & 52,17 & 64,52 & 38,09 \\
\hline 4 & ss & $\mathrm{mg} / \mathrm{l}$ & - & - & - & - & - & - & - & - & - & 0,00 & - & - \\
\hline 5 & $\mathrm{pH}$ & & 7,41 & 7,41 & 7,52 & 7,56 & 7,56 & 7,49 & 7,60 & 7,69 & 7,64 & 7,57 & 7,53 & 7,60 \\
\hline 6 & Alkalinitas & $\mathrm{mg} / \mathrm{l} \mathrm{CaCO}$ & 156,97 & 147,26 & 160,00 & 167,28 & 179,15 & 179,09 & 169,23 & 178,91 & 175,27 & 162,98 & 167,92 & 168,54 \\
\hline 7 & $\mathrm{CO} 2$ Bebas & $\mathrm{mg} / \mathrm{l} \mathrm{CO}$ & 12,22 & 11,62 & 10,18 & 9,67 & 9,35 & 11,62 & 8,49 & 7,27 & 8,56 & 9,12 & 10,48 & 8,54 \\
\hline 8 & DO & $\mathrm{mg} / \mathrm{l} \mathrm{O}$ & 2,78 & 2,86 & 3,26 & 3,31 & 2,68 & 3,28 & 3,66 & 3,58 & 3,01 & 3,10 & 3,02 & 3,11 \\
\hline 9 & Nitrit & $\mathrm{mg} / \mathrm{l} \mathrm{NO}{ }_{2}-\mathrm{N}$ & 0,14 & 0,06 & 0,03 & 0,07 & 0,17 & 0,12 & 0,09 & 0,09 & 0,09 & 0,08 & 0,08 & 0,13 \\
\hline 10 & Amonia & $\mathrm{mg} / \mathrm{l} \mathrm{NH}_{3}-\mathrm{N}$ & 1,29 & 0,40 & 0,28 & 0,22 & 0,28 & 0,32 & 1,56 & 0,85 & 1,45 & 1,87 & 1,49 & 1,30 \\
\hline 11 & Tembaga & $\mathrm{mg} / \mathrm{l} \mathrm{Cu}$ & - & - & - & 0,32 & 0,65 & 0,53 & 0,67 & 0,31 & 0,53 & 0,00 & 1,94 & 0,53 \\
\hline 12 & Phospat & $\mathrm{mg} / \mathrm{l} \mathrm{PO}_{4}$ & 0,15 & 0,17 & 0,11 & 0,13 & 0,22 & 0,23 & 0,14 & 0,19 & 0,25 & 0,23 & 0,21 & 0,17 \\
\hline 13 & Besi & $\mathrm{mg} / \mathrm{l} \mathrm{Fe}$ & - & - & - & 0,13 & 0,28 & 0,17 & 0,21 & 0,11 & 0,14 & 0,00 & 0,12 & 0,27 \\
\hline 14 & $\begin{array}{l}\text { Krom } \\
\text { Heksavalen }\end{array}$ & $\mathrm{mg} / \mathrm{l} \mathrm{Cr} r^{5+}$ & 0,01 & 0,01 & 0,01 & 0,04 & 0,06 & 0,05 & 0,05 & 0,03 & 0,06 & 0,15 & 0,06 & 0,03 \\
\hline 15 & Mangan & $\mathrm{mg} / \mathrm{l} \mathrm{Mn}$ & - & - & - & - & - & - & - & - & - & 0,00 & - & - \\
\hline 16 & Seng & $\mathrm{mg} / \mathrm{I} \mathrm{Zn}$ & - & - & - & - & - & - & - & - & - & 0,00 & - & - \\
\hline 17 & Timbal & $\mathrm{mg} / \mathrm{l} \mathrm{Pb}$ & - & - & - & - & - & - & - & - & - & 0,00 & - & - \\
\hline 18 & COD & $\mathrm{mg} / \mathrm{l} \mathrm{O}_{2}$ & 14,20 & 15,35 & 13,35 & 13,56 & 14,58 & 13,45 & 12,27 & 14,84 & 17,14 & 18,82 & 15,78 & 15,80 \\
\hline 19 & Detergen & $\mu \mathrm{g} / \mathrm{lt}$ MBAS & 86,30 & 73,56 & 72,43 & 85,04 & 70,04 & 73,69 & 56,26 & 49,87 & 48,68 & 79,11 & 60,46 & 61,72 \\
\hline 20 & $\mathrm{DHL}$ & $\mu \mathrm{S} / \mathrm{cm}$ & 520,00 & 436,00 & 466,00 & 510,50 & 547,00 & 416,00 & 430,00 & 447,00 & 464,00 & 472,00 & 430,00 & 433,00 \\
\hline 21 & Kesadahan & $\mathrm{mg} / \mathrm{l} \mathrm{CaCO}$ & 203,84 & 178,24 & 170,06 & 198,64 & 204,48 & 203,87 & 221,33 & 216,83 & 177,08 & 146,84 & 155,05 & 168,86 \\
\hline 22 & Nitrat & $\mathrm{mg} / \mathrm{l} \mathrm{NO}{ }_{3}-\mathrm{N}$ & 1,26 & 0,70 & 0,39 & 0,41 & 0,98 & 1,10 & 0,78 & 1,10 & 0,67 & 1,02 & 1,05 & 0,83 \\
\hline 23 & Silikat & $\mathrm{mg} / \mathrm{l} \mathrm{SiO}{ }_{2}-\mathrm{N}$ & 15,91 & 15,75 & 17,10 & 33,70 & 33,25 & 22,46 & 38,42 & 41,43 & 24,00 & 29,90 & 25,76 & 21,18 \\
\hline 24 & Zat Organik & $\mathrm{mg} / \mathrm{l} \mathrm{KMnO} 4$ & 16,46 & 16,87 & 13,18 & 16,17 & 15,69 & 15,45 & 13,14 & 10,61 & 12,53 & 22,71 & 14,76 & 16,65 \\
\hline 25 & $B O D$ & $\mathrm{mg} / \mathrm{l} \mathrm{O}_{2}$ & 11,75 & 12,00 & 12,50 & 12,00 & 11,50 & 11,25 & 9,67 & 11,75 & 11,75 & 12,00 & 12,50 & 11,25 \\
\hline 26 & Kalsium & $\mathrm{mg} / \mathrm{l} \mathrm{CaCO}$ & 136,53 & 146,26 & 138,03 & 146,15 & 136,30 & 146,26 & 151,67 & 149,87 & 122,33 & 95,75 & 114,77 & 117,08 \\
\hline 27 & Magnesium & $\mathrm{mg} / \mathrm{l} \mathrm{Mg}$ & 16,36 & 7,77 & 7,78 & 12,76 & 16,57 & 14,00 & 16,93 & 16,27 & 13,30 & 12,42 & 9,79 & 12,58 \\
\hline 28 & Klorida & $\mathrm{mg} / \mathrm{l} \mathrm{Cl}$ & 32,20 & 24,29 & 21,51 & 26,41 & 30,79 & 28,90 & 24,42 & 26,07 & 26,53 & 27,65 & 23,70 & 24,74 \\
\hline 29 & Sulfat & $\mathrm{mg} / \mathrm{l} \mathrm{SO}$ & - & 42,61 & 28,65 & 63,78 & 62,10 & 50,67 & 67,16 & 45,70 & 54,82 & 95,63 & 72,90 & 75,66 \\
\hline 30 & Fluorida & $\mathrm{mg} / \mathrm{l} \mathrm{F}$ & 0,67 & 0,35 & 0,61 & 0,22 & $\mathrm{ttd}$ & $\mathrm{ttd}$ & 0,10 & 0,43 & 0,46 & 1,57 & 0,26 & 0,34 \\
\hline 31 & Arsen & $\mathrm{mg} / \mathrm{l}$ As & - & - & - & - & - & - & - & - & - & - & - & - \\
\hline 32 & Kadmium & $\mathrm{mg} / \mathrm{l} \mathrm{cd}$ & - & - & - & - & - & - & - & 0,00 & 0,00 & 0,00 & 0,00 & 0,00 \\
\hline 33 & Phenol & $\mu \mathrm{g} / \mathrm{l}$ & 0,28 & 0,25 & 0,40 & 0,19 & 0,31 & 0,34 & 0,22 & 0,37 & 0,27 & 0,23 & 0,60 & 0,23 \\
\hline 34 & Total Coli & $\mathrm{Jml} / 100 \mathrm{ml}$ & 72500 & 386667 & 221250 & 131500 & 313250 & 163250 & 313333 & 295750 & 191000 & 351500 & 557500 & 217500 \\
\hline 35 & Fecal coli & $\mathrm{Jml} / 100 \mathrm{ml}$ & 24025 & 92333 & 32500 & 42000 & 45500 & 36250 & 53333 & 33250 & 36333 & 23225 & 25000 & 55500 \\
\hline 36 & Aluminium & mg/l Al & - & - & - & - & - & - & - & - & - & - & - & - \\
\hline
\end{tabular}


Tabel 3 : Hasil Analisa Kualitas Air Baku Rata-Rata Bulanan Instalasi Penjernihan Ngagel Tahun 2017.

\begin{tabular}{|c|c|c|c|c|c|c|c|c|c|c|c|c|c|}
\hline \multirow{2}{*}{ Parameter } & \multirow{2}{*}{ Satuan } & \multirow{2}{*}{$\begin{array}{c}\text { Standart } \\
\text { Maksimal *) }\end{array}$} & \multicolumn{11}{|c|}{ Bulan ke- } \\
\hline & & & Jan & Feb & Mar & Apr & May & Jun & Jul & Aug & Sep & Oct & Nov \\
\hline Suhu & ${ }^{\circ} \mathrm{C}$ & deviasi 3 & 26,70 & 26,24 & 26,94 & 27,27 & 27,40 & 27,05 & 26,77 & 26,71 & 27,50 & 28,47 & 27,66 \\
\hline Kekeruhan & Skala NTU & - & 146,57 & 143,75 & 165,98 & 174,95 & 52,22 & 25,83 & 21,58 & 18,34 & 16,75 & 14,23 & 87,16 \\
\hline Warna & Pt-Co & - & 36,21 & 15,46 & 20,76 & 49,73 & 30,31 & 12,15 & 17,86 & 12,50 & 13,55 & 13,45 & 16,71 \\
\hline ss & $\mathrm{mg} / \mathrm{l}$ & 50 & - & - & 222,38 & 188,11 & 72,00 & 48,13 & 43,10 & 45,00 & 36,95 & 33,59 & 57,00 \\
\hline $\mathrm{pH}$ & & $6.5-8.5$ & 7,53 & 7,40 & 7,36 & 7,21 & 7,38 & 7,45 & 7,55 & 7,46 & 7,53 & 7,42 & 7,29 \\
\hline Alkalinitas & $\mathrm{mg} / / \mathrm{CaCO}$ & - & 172,91 & 167,96 & 171,93 & 160,82 & 170,32 & 175,56 & 181,38 & 183,06 & 179,80 & 166,03 & 132,06 \\
\hline $\mathrm{CO} 2$ Bebas & $\mathrm{mg} / \mathrm{l} \mathrm{CO}{ }_{2}$ & - & 11,17 & 13,55 & 15,23 & 20,86 & 14,50 & 12,57 & 10,33 & 11,07 & 10,71 & 12,76 & 16,60 \\
\hline DO & $\mathrm{mg} / \mathrm{IO}_{2}$ & Min. 4 & 3,19 & 3,65 & 3,68 & 2,71 & 2,99 & 2,63 & 3,54 & 2,98 & 2,80 & 2,53 & 2,37 \\
\hline Nitrit & $\mathrm{mg} / \mathrm{l} \mathrm{NO}{ }_{2}-\mathrm{N}$ & 0,06 & 0,13 & 0,06 & 0,07 & 0,09 & 0,10 & 0,09 & 0,06 & 0,09 & 0,18 & 0,08 & 0,11 \\
\hline Amonia & 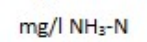 & - & 0,96 & 1,11 & 1,08 & 1,39 & 1,49 & 1,36 & 1,08 & 1,14 & 1,36 & 1,23 & 1,78 \\
\hline Tembaga & $\mathrm{mg} / \mathrm{l} \mathrm{Cu}$ & 0,02 & 0,27 & $<0.114$ & $<0.114$ & 0,21 & 0,30 & \#DIV/o! & $<0.114$ & 0,30 & $<0.114$ & $<0.114$ & 0,16 \\
\hline Phospat & $\mathrm{mg} / \mathrm{l} \mathrm{PO}_{4}$ & 0,2 & 0,16 & 0,12 & 0,15 & 0,15 & 0,16 & 0,23 & 0,17 & 0,14 & 0,15 & 0,10 & 0,15 \\
\hline $\begin{array}{l}\text { Besi } \\
\text { Krom }\end{array}$ & $\mathrm{mg} / \mathrm{l} \mathrm{Fe}$ & - & 0,40 & 0,06 & 0,05 & 0,20 & 0,17 & 0,11 & 0,13 & $<0.0551$ & $<0.0551$ & 0,06 & 0,18 \\
\hline Heksavalen & $\mathrm{mg} / \mathrm{l} \mathrm{Cr}^{5+}$ & 0,05 & 0,01 & 0,01 & 0,01 & 0,02 & 0,01 & 0,02 & 0,01 & 0,00 & 0,00 & 0,01 & 0,02 \\
\hline Mangan & $\mathrm{mg} / \mathrm{l} \mathrm{Mn}$ & - & $<0.012395$ & 0,02 & 0,02 & 0,00 & - & 0,00 & 0,06 & 0,08 & 0,21 & 0,07 & 0,04 \\
\hline Seng & $\mathrm{mg} / \mathrm{Zn}$ & 0,05 & 0,00 & 0,01 & 0,00 & 0,00 & - & 0,00 & $<0.000322$ & 0,00 & 0,01 & 0,01 & 0,01 \\
\hline Timbal & $\mathrm{mg} / \mathrm{l} \mathrm{Pb}$ & 0,03 & $<0.005922$ & $<0.005573$ & $<0.005757$ & $<0.005804$ & - & 0,00 & $<0.005897$ & $<0.009704$ & - & $<0.007122$ & $<0.005527$ \\
\hline COD & $\mathrm{mg} / \mathrm{l} \mathrm{O}_{2}$ & 25 & 14,80 & 17,71 & 17,87 & 17,03 & 19,26 & 19,00 & 16,77 & 17,20 & 15,08 & 12,94 & 14,52 \\
\hline Detergen & $\mu \mathrm{g} / \mathrm{lt}$ MBAS & 200 & 56,43 & 62,35 & 57,94 & 56,68 & 69,53 & 61,30 & 89,35 & 51,82 & 52,62 & 54,39 & 200,04 \\
\hline DHL & $\mu \mathrm{S} / \mathrm{cm}$ & - & 425,00 & 375,00 & 385,00 & 353,00 & 432,40 & 446,00 & 456,75 & 473,25 & 508,00 & 509,60 & 485,25 \\
\hline Kesadahan & $\mathrm{mg} / \mathrm{l} \mathrm{CaCO}{ }_{3}$ & - & 171,94 & 177,81 & 171,10 & 150,18 & 167,19 & 209,32 & 176,76 & 151,50 & 159,08 & 178,68 & 168,49 \\
\hline Nitrat & $\mathrm{mg} / \mathrm{l} \mathrm{NO} \mathrm{S}_{3}-\mathrm{N}$ & 10 & 1,25 & 0,56 & 0,75 & 0,54 & 0,73 & 0,37 & 0,67 & 0,45 & 0,41 & 1,21 & 0,72 \\
\hline Silikat & $\mathrm{mg} / \mathrm{l} \mathrm{SiO}{ }_{2}-\mathrm{N}$ & - & 23,79 & 10,30 & 23,00 & 13,18 & 24,36 & 31,43 & 27,95 & 25,16 & 16,46 & 26,12 & 23,69 \\
\hline Zat Organik & $\mathrm{mg} / / \mathrm{KMnO} 4$ & - & 20,18 & 24,07 & 15,51 & 19,22 & 13,03 & 12,36 & 9,47 & 9,22 & 8,05 & 11,89 & 14,34 \\
\hline$B O D$ & $\mathrm{mg} / \mathrm{l} \mathrm{O}_{2}$ & 3 & 11,75 & 11,75 & 11,75 & 12,25 & 11,80 & 10,33 & 8,75 & 6,25 & 6,75 & 7,80 & 7,75 \\
\hline Kalsium & $\mathrm{mg} / \mathrm{l} \mathrm{CaCO}$ & - & 128,71 & 137,61 & 116,26 & 112,19 & 115,22 & 134,80 & 121,90 & 112,38 & 121,44 & 124,78 & 144,99 \\
\hline Magnesium & $\mathrm{mg} / \mathrm{l} \mathrm{Mg}$ & - & 10,51 & 9,77 & 12,44 & 9,23 & 12,63 & 18,11 & 13,33 & 9,51 & 9,15 & 13,10 & 5,71 \\
\hline Klorida & $\mathrm{mg} / \mathrm{l} \mathrm{cl}$ & - & 24,83 & 22,24 & 25,35 & 19,65 & 25,12 & 24,70 & 22,67 & 22,43 & 25,33 & 23,82 & 29,41 \\
\hline Sulfat & $\mathrm{mg} / \mathrm{lsO}_{4}$ & - & 84,50 & 80,42 & 76,29 & 88,39 & 81,76 & 80,90 & 82,73 & 156,78 & 179,48 & 30,22 & 45,33 \\
\hline Fluorida & $\mathrm{mg} / \mathrm{l} \mathrm{F}$ & 1,5 & 1,62 & 0,13 & 0,88 & 0,13 & 0,54 & 0,43 & 0,59 & 1,00 & 0,35 & 0,54 & 1,52 \\
\hline Arsen & $\mathrm{mg} / \mathrm{l} \mathrm{As}$ & 1 & - & - & - & - & - & - & - & - & - & - & - \\
\hline Kadmium & $\mathrm{mg} / \mathrm{l} \mathrm{cd}$ & 0,01 & $<0.000315$ & 0,02 & $<0.000310$ & $<0.000286$ & $<0,000277$ & $<0.000298$ & $<0.000297$ & $<0.000301$ & $<0.000346$ & $<0.000394$ & $<0.000326$ \\
\hline Phenol & $\mu \mathrm{g} / \mathrm{l}$ & 1 & 0,18 & 0,19 & 0,08 & 0,15 & 0,30 & 0,09 & 0,15 & 0,16 & 0,19 & 0,19 & 0,18 \\
\hline Total Coli & $\mathrm{Jml} / 100 \mathrm{ml}$ & 5000 & 81750 & 196500 & 71500 & 46000 & 108800 & 283333 & 102500 & 55500 & 62500 & 33320 & 9025 \\
\hline $\begin{array}{l}\text { Fecal coli } \\
\text { Aluminium }\end{array}$ & $\begin{array}{c}\mathrm{Jml} / 100 \mathrm{ml} \\
\mathrm{mg} / \mathrm{l} \mathrm{Al}\end{array}$ & $\begin{array}{c}1000 \\
0,2\end{array}$ & 19750 & 28000 & $\begin{array}{c}19500 \\
0,16\end{array}$ & 14750 & 29020 & 87000 & $\begin{array}{c}27750 \\
0,07\end{array}$ & $\begin{array}{c}23000 \\
0,08\end{array}$ & $\begin{array}{c}18250 \\
0,11\end{array}$ & $\begin{array}{c}11400 \\
0,12\end{array}$ & $\begin{array}{l}3800 \\
0,08\end{array}$ \\
\hline
\end{tabular}

